WPS3701

\title{
The Doha Round, Poverty and Regional Inequality in Brazil
}

\author{
by \\ Joaquim Bento de Souza Ferreira Filho * \\ and \\ Mark Horridge **
}

Chapter 7 in Putting Development Back into the Doha Agenda: Poverty Impacts of a WTO

Agreement, Thomas W. Hertel and L. Alan Winters (eds.) forthcoming from the World Bank, Washington, D.C.

World Bank Policy Research Working Paper 3701, September 2005

The Policy Research Working Paper Series disseminates the findings of work in progress to encourage the exchange of ideas about development issues. An objective of the series is to get the findings out quickly, even if the presentations are less than fully polished. The papers carry the names of the authors and should be cited accordingly. The findings, interpretations, and conclusions expressed in this paper are entirely those of the authors. They do not necessarily represent the view of the World Bank, its Executive Directors, or the countries they represent. Policy Research Working Papers are available online at http://econ.worldbank.org.

* Escola Superior de Agricultura “Luiz de Queiroz”, Universidade de São Paulo. Departamento de Economia, Administração e Sociologia. Av. Pádua Dias, 11. Piracicaba, SP. CEP 13.418-900. Tel: (019) 34178700. Email: jbsferre@esalq.usp.br

** Centre of Policy Studies, Monash University. Melbourne, Australia. Email: Mark.Horridge@buseco.monash.edu.au. 


\begin{abstract}
This paper addresses the potential effects of the Doha round of trade negotiations on poverty and income distribution in Brazil, using an applied general equilibrium (AGE) and micro-simulation model of Brazil tailored for income distribution and poverty analysis. Of particular importance is the fact that the representative household hypothesis is replaced by a detailed representation of households. The model distinguishes 10 different labor types, and has 270 different household expenditure patterns. Income can originate from 41 different production activities (which produce 52 commodities), located in 27 different regions in the country. The AGE model communicates to a micro-simulation model that has 112,055 Brazilian households and 263,938 adults.

Poverty and income distribution indices are computed over the entire sample of households and persons, before and after the policy shocks. Model results show that even important trade policy shocks, such as those applied in this study, do not generate dramatic changes in the structure of poverty and income distribution in the Brazilian economy. The simulated effects on poverty and income distribution are positive, but rather small. The benefits are, concentrated in the poorest households.
\end{abstract}




\section{Introduction}

One of the most striking aspects of the Brazilian economy is its high degree of income concentration. Despite the changes the economy has faced in the last 20 years, ranging from the country's re-democratization, trade liberalization, hyperinflation, many currency changes, and finally, to the macroeconomic stabilization in the mid-1990s, the country still shows one of the worst patterns of income distribution in the world. The resilience of this income distribution problem has attracted the attention of researchers worldwide, and is the central point of a lively debate in Brazil. The problem is, of course, extremely complex, and related to a great number of socio-economic variables, which makes it a particularly difficult analytical issue, since the effect of many variables on poverty is uncertain.

At the same time, new changes in the external environment face the Brazilian economy. The Doha Round of international trade negotiations may be one of the most important. A complex phenomenon in itself, the economic integration poses new questions relating to the prospects for the poor. This paper offers an attempt to address these questions with a systematic and quantitative approach. For this purpose, an applied general equilibrium model of Brazil tailored for income distribution and poverty analysis will be used. The model also has a regional breakdown, so we can examine the associated issue of regional inequality.

The plan of the paper is as follows: the next section shows some figures about the problem of poverty and income distribution in Brazil, with a brief review of the recent literature on the topic. Then, we present the methodological approach to be pursued here, with a discussion of the relevant literature on the many different approaches. Then the model itself is presented, 
with a discussion of its main aspects and of the database. Finally, results and conclusions are presented.

\section{Poverty and income distribution evolution in Brazil: An overview}

Although Brazil is a country with a large number of poor people, its population is not among the poorest in the world. Drawing on the 1999 Report on Human Development, Barros et al (2001) show that around 64 percent of the countries in the world have per capita income less than in Brazil, a figure that mounts to 77 percent if we consider the number of persons in the same condition. The same authors show that, while in Brazil 30 percent of the total population is poor, on average only 10 percent are poor in other countries with similar per capita income. Indeed, based on the same report the authors define an international norm that, based on per capita income, would impute only 8 percent of poor for Brazil. That is, if the inequality of income in Brazil were to correspond to the world average inequality for countries in the same per capita income range just 8 percent (rather than 30 percent) of the Brazilian population would be expected to be poor.

Taking the concept of poverty in its particular dimension of income insufficiency, the same authors show that in 1999 about 14 percent of the Brazilian population lived in households with income below the line of extreme poverty (indigence line, about 22 million people), and 34 percent of the population lived in households with income below the poverty line (about 53 million people). Even though the percentage of poor in the population has declined from 40 percent in 1977 to 34 percent in 1999, this level is still very high and, it seems, stable. The size of poverty in Brazil, measured either as a percentage of the population or in terms of a poverty gap, stabilizes in the second half of the 1980s, although at a lower level than was observed in the previous period. 
Barros and Mendonça (1997) have analyzed the relations between economic growth and reductions in the level of inequality upon poverty in Brazil. Among their main conclusions, these authors point out that an improvement in the distribution of income would be more effective for poverty reduction than economic growth alone, if growth maintained the current pattern of inequality. According to these authors, due to the very high level of income inequality in Brazil it is possible to dramatically reduce poverty in the country even without economic growth, just by turning the level of inequality in Brazil close to what can be observed in a typical Latin American country.

Brazilian poverty also has an important regional dimension. According to calculations by Rocha (1998) in a study for the 1981/95 period the richer South-East region of the country, while counting for 44 percent of total population in 1995 had only 33 percent of the poor. These figures were 15.4 percent for the South region (8.2 percent of poor), and 6.8 percent for the Center-West region (5.2 percent of poor). For the poorer regions, on the contrary, the share of population in each region is lower than the share of poor: 4.6 percent (9.3 percent of poor) for the North region, and 29.4 percent (44.3 percent of poor) for the North-East region, the poorest region in the country.

In terms of evolution of regional inequality, Rocha (1998) concludes that no regular trend could be observed in the period. Moreover, the author also concludes that the yearly observed variations in concentration are mainly related to what happens in the state of São Paulo (SouthEast region) and in the North-East region. This reinforces the position of these two regions in the extremes of the regional income distribution in Brazil. The author also points out that once the effects of income increase that followed the end of the hyper-inflation period in 1995 run out, reduction of national and regional poverty will depend mainly on the macroeconomic 
determinants related to investment. Also, the author conclude that even keeping unchanged the actual level of poverty, reductions in regional inequality will require reallocation of industrial activity to peripheral regions.

And, finally, the same author also concludes that opening of the economy to the external market (mainly in relation to the formation of Mercosul) would help reduce regional inequality in Brazil. This would happen through reduced consumer prices in the poorest regions, which are fortunately lacking in the industries most threatened by new trade flows.

The behavior of wages and the allocation of labor throughout the 1980-99 trade liberalization period in Brazil was analyzed by Green et al (2001). Among the main findings the authors point out that wage inequality remained fairly constant for the 1980s and 1990s, with a small peak in the mid 80s. The main conclusion of the study is that the egalitarian consequences of trade liberalization were not important in Brazil for the period under analysis. As caveats, the authors note the low trade exposure of the Brazilian economy (around 13 percent in 1997), as well as the low share of workers that have completed college studies in total (1 in 12 workers at that time).

Gurgel, Harrison, Rutherford and Tarr (2003) present a CGE analysis of the effects on Brazil of trade liberalization. They use a GTAP-derived multi-country model with additional Brazilian detail. For Brazil, 10 urban and 10 rural household income types are recognized. The paper compares the effects of the FTAA, EU-MERCOSUL, and multilateral trade agreements on Brazil. Amongst variant scenarios are: the effects of FTAA or EU-MERCOSUL if the USA/EU did not offer free access to Brazilian farm products; and the interaction between trade deals, eg, whether FTAA makes EU-MERCOSUL less attractive. They conclude that the trade deals are in varying degrees good for Brazil, and especially good for Brazil's poor. The poor benefit more 
because they tend to work in agriculture, which is export-oriented and currently suffers from both foreign trade barriers and protection of local manufacturing.

\section{Methodology}

Computable general equilibrium (CGE) models have long been used for poverty analysis. Many CGE models use a single representative household to represent consumer behavior in the model. This formulation, although adequate for many purposes, limits the investigation of poverty and income distribution analysis. More recent approaches were developed to deal with these constraints.

Savard (2003) provides a thorough discussion of the topic. According to him, CGE models dealing with poverty and income distribution analysis can be classified into three main categories: models with a single representative household (RH), models with multiplehouseholds (MH), and the micro-simulation approach that links a CGE model to an econometric household micro-simulation model.

The representative household model is the traditional method, and has been widely used in the literature. The main drawback of this model for income distribution and poverty analysis is that there are no intra-group income distribution changes, as the households are all aggregated into a single representative.

The second approach, the multiple-household model (MH), consists of multiplying the number of households. For example, the afore-mentioned Gurgel et al. study distinguished 20 household types. Since they have varying expenditure and income source shares, the households are affected differently by economic changes. However, income or other differences within a particular household group are ignored. 
Increasing computation capacity allows us to have a large number of households in an MH model. To take an extreme case, the total number of households in a household survey could be used. This approach then allows the model to take into account the full detail in household data, and avoids pre-judgment about aggregating households into categories. The main disadvantages of this type of approach are that data reconciliation can be difficult, and that the size of the model can become a constraint.

The third approach, which we call MS, draws on micro-simulation techniques. Here, a CGE model generates aggregate changes that are later communicated to a micro-simulation model based on a large unit record database. Savard (2003) points out that the drawbacks to the approach are coherence between models, since the causality usually runs from the CGE model to the micro-simulation model, with no feedback between them.

The approach pursued in this paper takes advantage of the same general idea raised by Savard (2003) to overcome the difficulties posed by the three first options above-mentioned: the use of a CGE model linked to a micro-simulation model, but with a bi-directional linkage between them that would guarantee a convergence of solution for both models. Savard (2003) links the models by running them in a repeated sequence of CGE-MS model runs, first computing the CGE simulation, then the MS model simulation, in a looping way, until convergence occurs. The main advantages of this approach are that: we avoid scaling the microeconomic data to match the aggregated macro data; we can accommodate more households in the MS model; and the MS model may incorporate discrete-choice or integer behavior that might be difficult to incorporate in the CGE model.

The CGE model used here is a static inter-regional model of Brazil based on the wellknown ORANI-G model of Australia (Horridge, 2000). The model's structure is quite standard: 
consumption is modeled through the Linear Expenditure System over composite commodities (domestic and imported); exporters of each commodity face constant-elasticity ${ }^{1}$ foreign demand schedules; production for exports or domestic markets are regulated by $\mathrm{CET}^{2}$ functions for each firm, production is a nested Leontief/CES structure for primary factors and composite inputs, labor is a CES function of 10 different types of labor. This non-linear model is solved with the GEMPACK software, and distinguishes between 42 sectors and 52 commodities $^{3}$; 10 labor occupational categories.

All quantity variables in the model are disaggregated according to 27 regions within Brazil, using an elaboration of the top-down regional modeling method described in Chapter 6 of Dixon et al. (1982). This methodology recognizes local multiplier effects: many service goods are little traded between regions, so that local service output must follow local demand for services.

The CGE model is calibrated with data from the Brazilian economy for 1996, obtained from two main sources: the 1996 Brazilian Input-Output Matrix (IBGE. http://ibge.gov.br), and the Brazilian Agricultural Census (IBGE, 1996).

On the income generation side of the model, workers are divided into 10 different categories (occupations), according to their wages. These wage classes are then assigned to each regional industry in the model. Together with the revenues from other endowments (capital and land rents) these wages will be used to generate household incomes. Each activity uses a particular mix of the 10 different labor occupations (skills). Changes in activity level change

\footnotetext{
${ }^{1}$ For the simulations reported here, we set the export demand elasticities to values derived from the GTAP model, so as to increase consistency between results for the world and Brazil models.

${ }^{2}$ The domestic/exportable CET was set to infinity for the simulations reported below, to fit in with the assumptions of the GTAP model.

${ }^{3}$ One of the activities (Agriculture) produces 11 commodities.
} 
employment by sector and region. This drives changes in poverty and income distribution. Using the POF (the expenditure survey) data mentioned below, we extend the CGE model to cover 270 different expenditure patterns, composed of 10 different income classes in 27 regions. In this way, all the expenditure side detail of our micro-simulation dataset is incorporated within the main CGE model.

There are two main sources of information for the household micro-simulation model: the Pesquisa Nacional por Amostragem de Domicílios -PNAD (National Household Survey - IBGE, 2001), and the Pesquisa de Orçamentos Familiares- POF (Household Expenditure Survey, IBGE, 1996). The PNAD contains information about households and persons, and shows a total of 331,263 records. The main information extracted from PNAD were wage by industry and region, as well as other personal characteristics such as years of schooling, sex, age, position in the family, and other socio-economic characteristics.

The POF, on the other hand, is an expenditure survey that covers 11 metropolitan regions in Brazil. It was undertaken during 1996, and covered 16,014 households, with the purpose of updating the consumption bundle structure. The main information we drew from this survey was the expenditure patterns of 10 different income classes, for the 11 regions. We assigned one such pattern to each individual PNAD household, according to each income class. As for the regional dimension, the 11 POF regions were mapped to the larger set of 27 CGE regions. Here it must be stressed that the POF survey just brings information about urban areas (the metropolitan areas of the main state capitals).

\subsection{Model running procedures and highlights}

As mentioned before, our model consists of two main parts: a Computable General Equilibrium model (CGE) and a Household Model (MS). The models are run sequentially. To 
ensure consistency between the two models we have two strategies. First of all, the CGE model is sufficiently detailed, and its categories and data are close enough to those of the MS model that the CGE model predicts MS behavior (that is also included in the CGE model, such as household demands or labor supplies) very closely. The role of the MS model is to provide extra information, for example about the variance of income within income groups, or about the incidence of price and wage changes upon groups not identified by the CGE model, such as groups identified by ethnic type, educational level, or family status.

A second consistency strategy is that, if the MS model predicts household demands or labor supplies at variance with the CGE model we have the option of feeding back corrections into the CGE model, and running the two models iteratively until they agree. That option was not exercised in the simulations reported here ${ }^{4}$.

We start with a set of trade shocks generated by a GTAP model simulation that excludes the effect of Brazil's own tariff reductions. These shocks consist of changes in import prices and in export demands. To these shocks we add the Brazilian tariff shocks (the trade liberalization in Brazil). Import prices and tariffs are naturally exogenous to the Brazil model. We apply the export demand changes via vertical shifts in the export demand curves facing Brazil.

The trade shocks are applied, and the results calculated for 52 commodities, 42 industries, 10 households and 10 labor occupations -- all of which vary by 27 regions. Next, the results from the CGE model are used to update the MS model. At first, this update consists basically in updating wages and hours worked for the 263,938 workers in the sample. These changes have a regional (27 regions) as well as sectoral (42 industries) dimension.

\footnotetext{
${ }^{4}$ As in GTAP, labour supplies were fixed. Further, each household in our micro data set had one of the 270 expenditure patterns identified in the main CGE model. There is very little scope for the MS to disagree with the CGE model.
} 
The model then relocates jobs according to changes in labor demand ${ }^{5}$. This is done by changing the PNAD weight of each worker (see Annex for details) in order to mimic the change in employment -- we call this the "quantum weights method"“6 In this approach, then, there is a true job relocation process going on. Although the job relocation has very little effect on the distribution of wages between the 270 household groups identified by the CGE model, it may have considerable impact on the variance of income within a group.

One final point about the procedure used in this paper should be stressed. Although the changes in the labor market are simulated for each adult in the labor force, the changes in expenditures and in poverty are tracked back to the household dimension. This is possible since PNAD has a key that links persons to households. Each household contains one or more adults, either working in a particular sector and occupation, or unemployed, as well as dependents. In our model then it is possible to recompose changes in the household income from the changes in individual wages. This is a very important aspect of the model, since it is likely that family income variations are cushioned, in general, by this procedure. If, for example, one person in some household loses his job but another in the same household gets a new job, household income may change little. Since households are the expenditure units in the model, we would expect household spending variations to be smoothed by this income pooling effect. On the other hand, the loss of a job will increase poverty more if the displaced worker is the sole earner in a household.

\footnotetext{
${ }^{5}$ The methodology is described in more detail in the Annex. Here we present only the main ideas.

${ }^{6}$ Mark Horridge developed this method for this project.
} 


\section{The base year picture}

In this section we extend the above description of poverty and income inequality in Brazil. The reference year for our analysis is 2001. Some general aggregated information about poverty and income inequality in Brazil can be seen in Table 1.

The rows of Table 1 correspond to household income classes, grouped according to POF definitions ${ }^{7}$, such that $\mathrm{POF}[1]$ is the lowest income class, and POF[10] the highest. A fair picture of income inequality in Brazil emerges from the table. We see that the first 5 income classes, while accounting for 52.6 percent of total population in Brazil, get only 17 percent of total income. The highest income class, on the other hand, accounts for 11 percent of population, and about 45 percent of total income. The Gini index associated with the income distribution in Brazil in 2001, calculated using an equivalent household ${ }^{8}$ basis, is 0.58, placing Brazil's income distribution among the world's worst.

The unemployment rate is also relatively higher among the poorer classes. This is a very important point to be noted, due to its relevance for modeling. The opportunity to get a new job is probably the most important element lifting people out of poverty: hence the importance for poverty modeling of allowing the model to capture the existence of a switching regime (from unemployment to employment), and not just changes in wages. As can be seen in Table 1 above, the unemployment rate reaches 36.5 percent among the lowest income group (persons above 15 years), and just 7.7 percent among the richest. The percentage of white people also increases considerably with household income, while the percentage of children decreases markedly.

\footnotetext{
${ }^{7}$ POF[1] ranges from 0 to 2 minimum wages, POF[2] from 2+ to 3, POF[3] from 3+ to 5, POF[4] from 5+ to 6, POF[5] from 6-8, POF[6] from 8-10, POF[7] from 10-15, POF[8] from 15-20, POF[9] from 20-30, and POF[10] above 30 minimum wages. The minimum wage in Brazil in 2001 was around US\$76.

${ }^{8}$ The equivalent household concept measures the subsistence needs of a household by attributing weights to its members: 1 to the head, 0.75 to the other adults, and 0.5 to the children (eg, to feed 2 persons does not cost double).
} 
Although the analysis does not specifically focus in gender and ethnical aspects, these are important indicators to take into account when analyzing results.

For the purpose of further describing the state of income insufficiency in Brazil we set a poverty line defined as one-third of the average household income ${ }^{9}$. According to that criterion 30.8 percent of the Brazilian households in 2001 would be poor ${ }^{10}$. This would comprise 96.2 percent, 76.6 percent and 53.5 percent respectively of households in the first three income groups $^{11}$, or 34.5 million out of 112 million households in 2001.

Table 2 shows how each POF group contributes to the three Foster-Greer-Thorbecke (1984) (FGT, for short) overall measures of poverty: FGT0 - the proportion of poor households (i.e., below the poverty line), FGT1 - the average poverty gap ratio (proportion by which household income falls below the poverty line), and FGT2 - a measure of inequality among the poor.

Table 2 shows a large average poverty gap for the two lowest income classes. Together these two income classes contribute to about half of the general average poverty gap index of the economy. The first income class, for example, falls below the poverty line by about $70 \%$. Thus, large income increases for the poor are needed to significantly change the number in poverty.

As stated before, this general poverty and inequality picture also has an important regional dimension in Brazil -- because economic activity is located mainly in the South-East region. This is particularly true of manufacturing; agriculture is more dispersed among regions.

Because poverty is defined here on an equivalent basis, a few (very large) families in middle incomes groups fall below the poverty line.

${ }^{9}$ This poverty line is equivalent to US\$ 48.00 in 2001.

${ }^{10}$ Barros et all (2001), working with a poverty line that takes into account nutritional needs, find that 34 percent of the Brazilian households were poor in 1999.

${ }^{11}$ The proportion of households below the poverty line in the other income groups are 0.284 percent for the $4^{\text {th }}, 0.14$ percent for the $5^{\text {th }}, 0.04$ percent for the $6^{\text {th }}, 0.008$ percent for the $7^{\text {th }}$, and 0.001 percent for the $8^{\text {th }}$. There are no households below the poverty line for the two highest income classes. 
Table 3 shows more information about the regional variation of poverty and income inequality. The map in Figure 1 shows where regions are located, and shades them according to proportions of households in poverty.

As it can be seen in Table 3, the states in the North (N) region account for 8 percent of total population, compared to 23.5 percent for the North-East (NE), 45 percent in the South-East (SE), 16 percent for South (S), and 7.2 percent for the Center-West (CW). In the SE region the state of São Paulo alone accounts for 22.9 percent of total Brazilian population.

The fourth column in Table 3 shows the share of households below the poverty line in each region, as a proportion of total regional households. The states in the NE region (states numbered from 8 to 16 in the table) plus the states of Tocantins and Para in the $\mathrm{N}$ region present the highest figures for this indicator, showing that these states are relatively poorer. If, however, regional population is taken into account, the fifth column show that the populous regions of Ceará, Pernambuco, Bahia, Minas Gerais and São Paulo give higher contributions to the FosterGreer-Thorbecke poverty gap index ${ }^{12}$. These figures are the contribution of each state to the total poverty gap index in Brazil expressed as a proportion of the poverty line (see column total). We can see that the average poverty gap in Brazil in 2001 is a 14.5 percent insufficiency of income to reach the poverty line.

The last column in Table 3 shows the regional insufficiency gap. The picture is similar to what was seen for the number of households below the poverty line, with the states in the NE regions plus the states of Tocantins and Para showing the highest poverty gaps. Two states in the South region (Santa Catarina and Rio Grande do Sul) show the lowest poverty gaps in Brazil, followed closely by São Paulo. Interesting enough, Amapa state (in the North region) shows a

\footnotetext{
${ }^{12}$ The poverty gap and poverty line values are constructed with "adult equivalent” per capita household income.
} 
poverty gap in line with the richer states of the S-SE. This result, however, should be viewed with caution, since that state has a very small share of total population and the result could be due to sampling bias. The PNAD survey does not cover the rural areas of the Northern states, where poverty is usually concentrated.

More information about the labor structure of the economy can be seen in Table 4 and Table 5. In these tables sectoral wage bills are split into the model's 10 occupational groups. The occupational groups are defined in terms of a unit wage ranking. More skilled workers, then, would be those in the highest income classes, and vice-versa. As can be seen in Table 4, Agriculture is the activity that uses more unskilled labor (40.5 percent of that sector's labor bill), while Petroleum and Gas Extraction and Petroleum Refinery are the most intensive users of skilled labor $\left(10^{\text {th }}\right.$ labor class) using activities, with Financial Institutions coming next. If labor inputs were measured in hours (rather than in values) the concentration of low-skill labor in Agriculture would be even more pronounced.

Agriculture is also the sector that hires most unskilled labor in Brazil, around 41 percent of total workers in income class 1 (Table 5). The Trade sector is the second largest employer of this type of labor. As for the higher income classes, we see that the Financial Institutions and Public Administration sectors hire the largest numbers of well-paid workers.

Table 6 shows the distribution of occupation wages (OCC) classes among the household income classes (POF classes). In this table, the rows show household income classes, while the columns show the wage earnings by occupation. It is evident from this table that the wage earnings of the higher wage occupations (OCC10, for example) are concentrated in the higher income households, and vice-versa. Most of the wages earned by workers in the first wage class (OCC1) accrue to the three poorest households, POF[1]-[3]. All the workers in the highest wage 
class, on the other hand, are located in households from the $8^{\text {th }}$ income class and above. We see, then, that the household income classes are highly positively correlated with the occupational wage earning classes.

\section{The simulations}

This paper presents results for the central Doha scenario and for the full-liberalization scenario.

\subsection{Model closure}

In choosing a model closure we aimed to mimic the GTAP model that generated the foreign price scenario. On the supply side, we fixed total national employment by occupation, with jobs moving freely between sectors and regions ${ }^{13}$. The model allows substitution between occupations, driven by relative wages. Similarly capital is fixed nationally but is mobile between sectors and regions. The Land stock (used just in the Agriculture activity) is fixed ${ }^{14}$. Since agriculture is an activity that produces 11 products, land is allocated to these competing products through relative prices, allowing the crop mix to change. On the demand side government and investment spending are fixed ${ }^{15}$, and a fixed trade balance enforces the national budget balance,

\footnotetext{
${ }^{13}$ There is a tension between our GTAP-like closure and Brazilian reality. The microdata show substantial unemployment of less-skilled groups in all regions. For the microsimulation we assumed that jobs created (or lost) in a region were allotted to (or taken from) households in that region. An alternate scenario, where fixed real wages replaced national labour constraints, yielded results similar to those reported here.

${ }^{14}$ The factor market closure causes the model to generate percent changes in prices for 10 labour types, capital and land, ie, price changes are uniform across regions. Percent changes in demand for each of the 12 factors vary in addition by sector and region. Each adult in the PNAD microdata is identified by region and labour type; those employed are also identified by sector. Changes in microdata poverty levels are driven by wage changes and by the redistribution of jobs between sectors and regions (and hence between households).

${ }^{15}$ In real terms, since the CPI is the model's numeraire.
} 
which is accommodated by changes in real consumption. The trade balance, then, drives the level of absorption. The consumer price index (CPI) is the model's numeraire.

Finally, tax revenue losses due to tariff cuts are replaced: real aggregate revenue from all indirect taxes is kept fixed, via a uniform endogenous change in the power of indirect taxes on sales to households. This mechanism is equivalent to a lump sum tax, of value proportional to each household's spending ${ }^{16}$. It also mimics the traditional method of raising tax revenues in Brazil, through indirect tax collection.

\section{Results}

\subsection{The CGE model results}

The Brazilian economy has a limited exposure to external trade. The shares of exports and imports in total GDP were respectively 7.0 percent and 8.9 percent in the 1996 base year. These shares have increased recently, but not by enough to significantly change this picture ${ }^{17}$. Table 7 shows more information about the structure of Brazilian external trade as well as of related parameters and production structure, while Table 8 shows the nature and size of the shocks applied to the model.

As stated before, the shocks applied to the model were generated by a previous run of the GTAP model, where the Doha scenarios were implemented. The GTAP effects on the Brazilian

\footnotetext{
${ }^{16}$ That is, neither the distribution of spending nor relative prices facing households are altered. With fixed labour supplies, distortion of any labour-leisure choice does not arise.

${ }^{17}$ The share of imports plus exports in Brazilian GDP in 2001 and 2002 were, respectively, 22.3 percent and 23.4 percent.
} 
economy were then transmitted to the Brazil CGE model through tariffs and import prices changes, and shifts in the demand schedules for the Brazilian exports ${ }^{18}$.

An inspection of Table 7 and Table 8 can give an idea of the importance of these shocks combined with the importance of each commodity in Brazilian external trade. As can be seen, Brazilian exports are spread among many different commodities, with no specialized trend. Raw agricultural products have very small share in total exports, composed almost entirely of soybeans. Processed food and agricultural-based exports (including wood and furniture, rubber, paper, textiles and apparel), however, account for a significant 0.369 share of total exports in the base year, highlighting the importance of Agriculture in the Brazilian economy.

Imports as a share of each domestic production are concentrated in wheat, oil, machinery, electric materials and electronic equipment, and chemical products. In terms of total import shares, however, oil products (raw and refined), machinery, electric materials and electronic equipment, and chemical products are the most important products.

Table 7 also shows some relevant parameters and other production characteristics of the model. The Armington elasticities are borrowed from the GTAP database. The same is true for the export demand elasticities (not shown in the table), made equal to the GTAP region-generic elasticity of substitution among imports in the Armington structure.

The Agriculture sector is modeled as a multi-production sector, producing 11 commodities. Thus the capital/labor ratio (ratio of values) in Table 7 is the same for every agricultural product. The value of land is not included in the value of capital here. If land was included, the value of the capital/labor ratio in agriculture would rise to 0.99. The value

\footnotetext{
${ }^{18}$ The shifts in the demand schedules for Brazilian exports were calculated using export price and quantity results from GTAP, together with export demand elasticities drawn from GTAP data.
} 
added/value of production column, on the other hand, includes the returns to land for Agriculture.

In what follows, we present some macro results in order to establish a benchmark for the regional and poverty analysis. When interpreting these results one should bear in mind that the model has a "top-down” inter-regional specification, meaning that regional results depend on national results, but not vice-versa. National macro results can be seen in Table 9.

Because the closure fixes total supply of all primary factors (land, the 10 categories of labor, and capital), GDP shows only a slight increase in the simulations. The real exchange rate rises (revaluation) as a result of the shocks, with corresponding gains in the external terms of trade.

For factor market results, recall that land is used only by Agriculture, while capital and the 10 types of labor are fixed nationally, but mobile between sectors. As we can see, the average (aggregated) capital rental increases in all scenarios. With capital stocks and labor fixed in total, the expanding industries would attract capital and labor from the contracting ones. In these industries those with falling capital/labor ratios increase the marginal productivity of capital, and hence capital returns, determining an increase in aggregated results. The price of land also shows a strong increase, reflecting the increase in production of activities using this factor (Agriculture). National changes in industry output are shown in Table 10.

As can be seen in Table 10, expanding industries in all scenarios are agriculture and agricultural related industries (the food industry in general). The only exception is the vegetable oils industry that contracts under full-lib. Model results show a general fall in activity in the Brazilian manufacturing sectors following the trade liberalization. This suggests that regions 
specializing in manufacturing would fare worse. The Doha results are similar, just differing in size (but not sign), when compared with the Full-lib scenario, with a few exceptions.

Table 11 shows regional results. In this table, states are grouped according to their macroregions inside Brazil. For each of the 10 labor types, total employment is fixed, so labor demand (and unemployment) will be redistributed among regions according to changes in regional industry output.. Employment falls in São Paulo and Rio de Janeiro in the Southeast region (the most populous and industrialized states), and also in Amazonas, DF (Brasilia) and Amapa.

The states of São Paulo and Rio de Janeiro are industrial states, hosting the bulk of Brazil's manufacturing. As seen before, manufacturing is contracting in general, in all three scenarios. The same effect drives the result for the Amazonas state, where there is a free exporting zone, while reduced mining activity drives the results for Amapa state.

Interestingly, the trade liberalization scenarios seem to redistribute economic activity towards poorer regions. However, this occurs because higher value-added sectors (manufacturing) shrink, and relatively lower value-added sectors (agriculture) grow.

\subsection{Poverty and income distribution results}

We saw in the previous section that model results are differentiated among regions and industries. The outcome of these changes on income and income inequality measures as well as over income-group-specific consumer price indices are presented in Table 12 and discussed below. In this table, the POF groups are groups of household income, being POF[1] the lowest one and POF[10] the highest. We see that the GINI index fell by 0.21 percent in the Doha scenario and 0.52 percent in the Full-lib case.

These results confirm the general understanding that the GINI index usually changes very little with policy measures in the short run, and accord with observed facts in Brazil in the last 15 
years. Even though the country faced a strong trade liberalization process in the nineties, it was observed that the GINI index changed very little in the period.

The CPI column in each scenario is the particular CPI change for each household income class, since the consumption bundle of each class is different. It is interesting to note that the bulk of the real income effect comes from the income generation side, and not from the fall in prices. Actually, there is a strong increase in some food products, like meats, in all scenarios, driven mainly by the liberalization in the rest of the world. This is in contrast with what was expected by Rocha (1998), mentioned before, who expected that opening the Brazilian economy to the external market would help reduce inequality in Brazil through reductions in prices in the poorest regions. Our results suggest that the CPI would actually go up more in the lowest income classes, but are more than compensated by the income elevation.

An important point to note is that the highest positive changes in household income are concentrated on the lowest income households, decreasing monotonically as household income increases. Indeed, as can be seen in Table 13, the reduction in the number of poor households is concentrated in the poorest groups. High positive figures in POF groups 7 and 8 are percentage changes over very low numbers, since there are very few poor households in these income classes $^{19}$.

The headcount ratio index (FGT0 in Table 13) captures only the extension of poverty, but is insensitive to its intensity (Hoffmann, 1998). The change in the intensity of poverty can be seen through the FGT1 index, the insufficiency of income ratio. A reduction in FTG1 means a reduction in the severity of poverty inside each household income class. As seen from Table 13,

\footnotetext{
${ }^{19}$ Some middle-income households have many family members. With low per-capita income, they fall below the poverty line.
} 
the FGT1 index decreases more than the headcount ratio in all scenarios. This means that there was actually an income distribution improvement, but not enough to drive a large number of persons (or households) out of poverty. This is due to the high value of those indices in the base year, as noted before.

We also computed separately (but do not tabulate here) the effects on Brazil of its own liberalization (assuming other countries did not liberalize). The Brazilian tariff reduction contributes very little to the Doha scenario and is dominated by the other countries' actions even in the full liberalization scenario.

Finally, Table 14 shows model results relating to the regional breakdown inside Brazil. These results summarize at regional level the outcome of the simulated scenarios, as a net effect of the regional industries. They reflect, then, the pattern of regional specialization in production.

Table 14 shows that the states of Amazonas, Amapa, São Paulo and Rio de Janeiro would be the only ones where the number of households below the poverty line would increase in both simulations, although slightly. Amazonas and Amapa have small populations, while São Paulo and Rio de Janeiro are the most densely populated and industrialized states in Brazil. As noted before, the result is related to the high concentration of contracting (high value-added ) industries in the regions of São Paulo, Rio de Janeiro and Amazonas, mainly automobiles, machinery and tractors, electric materials, electronic equipment, and other vehicles and spare parts, while the result for Amapa is driven by the mining industries.

\section{Concluding Remarks}

A series of points should be highlighted in wrapping up this discussion. The model results show that even important trade policy shocks, such as those applied here, do not generate dramatic changes in the structure of Brazilian poverty and income distribution. The simulated 
effects on poverty and income distribution are positive, but very small. This highlights two points, one related to the structure of the Brazilian economy, and other to an aspect of poverty.

We noted that the Brazilian economy is not very oriented towards external trade. The domestic market is far bigger and more important for the general economy than the external market, as researchers have long understood. This makes Brazil naturally less sensitive to tariff structure changes, as well as to changes in export demands.

But we should also note that approaching poverty by the household dimension, instead of by the personal dimension, and tracking the changes in the labor market from individual workers to households is an important modeling issue. In the PNAD 2001 data we used, the income of the head of the family accounts for about 65 percent of aggregated household income in Brazil. Using head-of-household income as a proxy for household income may poorly predict the effect of policy changes, as convincingly argued by Bourguignon et al (2003). If spending (and welfare) is in any sense a household phenomenon, this is the appropriate method. Even though there may be a somewhat higher computational cost associated with this procedure, it seems worthwhile.

The role played by the agriculture sector in the analysis should also be stressed. As seen before, agriculture still accounts for a large share of employment for the poorest in Brazil. Despite the steady decline over time of agricultural employment as a share of total employment we should not overlook the importance of agricultural policies for poverty alleviation in the country.

Finally, it should be noted that this study assesses only the static impact of trade liberalization scenarios. The research methodology here used fails to capture many other effects generally associated with external trade liberalization, such as endogenous technology 
improvements and other dynamic effects. Indeed, our results suggest that if any strong impact over poverty is to arise from trade liberalization it must be expected to arise from these other aspects. 


\section{References}

Barros, R.P; Mendonça, R.1997. O Impacto do Crescimento Econômico e de Reduções no Grau de Desigualdade sobre a Pobreza. IPEA. Texto para Discussão no. 528. 17p. Rio de Janeiro.

Barros, R.P; Corseuil, C.H; Cury, S. 2001. Salário Mínimo e Pobreza no Brasil: Estimativas que Consideram Efeitos de Equilíbrio Geral. IPEA. Texto para Discussão no. 779. 24p. Rio de Janeiro.

Barros, R.P; Henriques, R; Mendonça, R. 2001. A Estabilidade Inaceitável: Desigualdade e Pobreza no Brasil. IPEA. Texto para Discussão no. 800. 24p. Rio de Janeiro.

Bourguignon, F; Robilliard, A.S; Robinson,S. Representative versus real households in the macro-economic modeling of inequality. Working Paper no. 2003-05. DELTA. Department et Laboratoire D’Economie Théorique et Apliquée. Centre National de la Recherce

Scientifique. École des Hautes Études en Sciences Sociales. 41 p. 2003

Cury, S. 1998. Modelo de Equilíbrio Geral para Simulação de Políticas de Distribuição de Renda e Crescimento no Brasil. Doutorado. São Paulo, FGV.

Dixon, P., Parmenter, B., Sutton, J. and Vincent, D. (1982) ORANI: A Multisectoral Model of the Australian Economy, Amsterdam: North-Holland.

Foster, James, Joel Greer, and Erik Thorbecke 1984. A Class of Decomposable Poverty Measures, Econometrica 52: 761-765.

Green, F; Dickerson, A; Arbache, J.S. 2001. A Picture of Wage Inequality and the Allocation of Labor Through a Period of Trade Liberalization: The Case of Brazil. World Development. Vol. 29, no.11, pp.1923-1939.

Gurgel, A; Harrison, G.W.; Rutherford, T.F. and Tarr, D.G., 2003. Regional, Multilateral, and Unilateral Trade Policies of MERCOSUR for Growth and Poverty Reduction in Brazil, World Bank Research Working Paper No. 3051, May.

Hoffmann, R. 1998. Distribuição de Renda: Medidas de Desigualdade e Pobreza. São Paulo. Editora da Universidade de São Paulo. 276 p.

Horridge, J.M. 2000. ORANI-G: A General Equilibrium Model of the Australian Economy. Working Paper no. OP-93. Centre of Policy Studies. Monash University. Melbourne, Australia.

IBGE - Instituto Brasileiro De Geografia E Estatística. 1996. Censo Agropecuário do Brasil. 366p.Rio de Janeiro.

IBGE - Instituto Brasileiro De Geografia E Estatística. 2001. Pesquisa Nacional por Amostra de Domicílios. Brasil.

IBGE - Instituto Brasileiro De Geografia E Estatística. 1996. Pesquisa de Orçamentos Familiares. Brasil.

Rocha, S. 1998. Desigualdade Regional e Pobreza no Brasil: a Evolução - 1985/95. IPEA. Texto para Discussão no. 567. 21p. Rio de Janeiro. 
Savard, L. 2003. Poverty and Income Distribution in a CGE-household sequential model. International Development Research Centre - IDRC. Processed. 32p. 
Figure 1: Brazil states shaded according to proportion in poverty

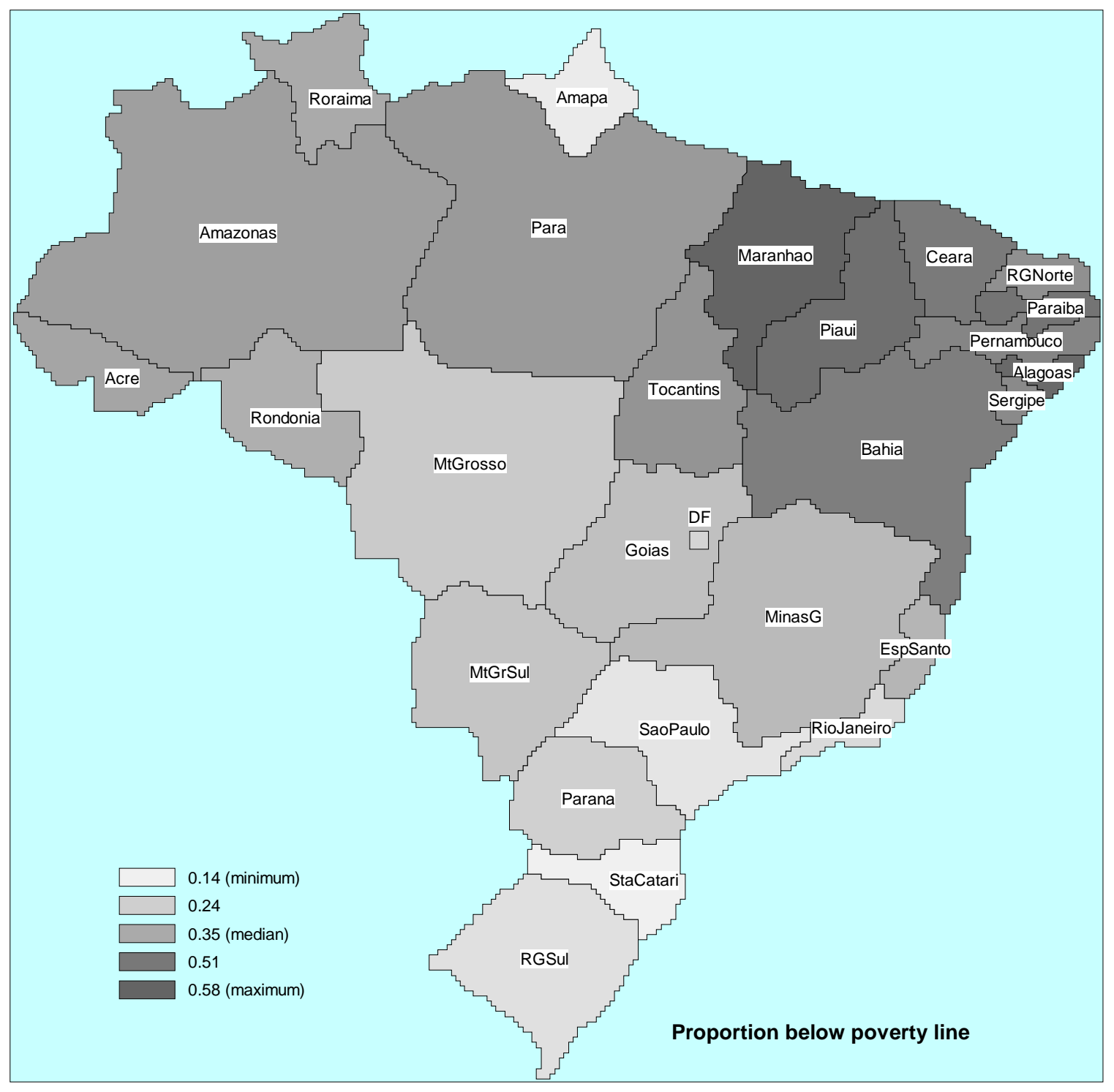


Table 1. Poverty and income inequality in Brazil, 2001.

\begin{tabular}{lrrrrrrr}
\hline $\begin{array}{c}\text { Income } \\
\text { group }\end{array}$ & PrPop & Princ & AveHouInc & UnempRate & PrWhite & AveWage & PrChild \\
\hline POF[1] & 10.7 & 0.9 & 0.1 & 32.6 & 35.2 & 0.2 & 46.2 \\
POF[2] & 8.0 & 1.8 & 0.4 & 17.3 & 38.3 & 0.3 & 37.2 \\
POF[3] & 16.0 & 5.2 & 0.6 & 10.4 & 42.0 & 0.4 & 35.1 \\
POF[4] & 7.3 & 3.1 & 0.8 & 8.8 & 45.1 & 0.4 & 32.5 \\
POF[5] & 11.0 & 5.8 & 1.0 & 7.5 & 49.2 & 0.5 & 28.7 \\
POF[6] & 7.9 & 5.1 & 1.2 & 7.4 & 53.4 & 0.6 & 26.4 \\
POF[7] & 12.9 & 11.1 & 1.7 & 6.8 & 60.3 & 0.8 & 24.5 \\
POF[8] & 7.5 & 8.7 & 2.3 & 6.1 & 66.3 & 0.9 & 21.5 \\
POF[9] & 7.7 & 12.7 & 3.1 & 5.9 & 71.2 & 1.4 & 20.5 \\
POF[10] & 10.9 & 45.7 & 7.9 & 4.2 & 81.6 & 3.2 & 17.7 \\
\hline Total & 100.0 & 100.0 & --- & -- & -- & --- & -- \\
\hline
\end{tabular}

PrPop = \% in total population; PrInc = \% in country total income; AveHouInc = average household income; UnempRate $=$ unemployment rate; PrWhite $=\%$ of white population in total; AveWage $=$ average normalized wage; PrChild = share of population under 15 by income class.

Source: PNAD, 2001. 
Table 2. POF group contributions to FGT poverty indices

\begin{tabular}{|c|c|c|c|c|c|c|}
\hline $\begin{array}{l}\text { POF } \\
\text { group }\end{array}$ & $\begin{array}{l}\% \text { of all } \\
\text { families }\end{array}$ & $\begin{array}{l}\text { Share below } \\
\text { poverty line }\end{array}$ & $\begin{array}{c}\text { Average } \\
\text { poverty gap }\end{array}$ & $\begin{array}{l}\text { Contributions } \\
\text { to FGT0 }\end{array}$ & $\begin{array}{l}\text { Contributions } \\
\text { to FGT1 }\end{array}$ & $\begin{array}{l}\text { Contributions } \\
\text { to FGT2 }\end{array}$ \\
\hline $\begin{array}{l}\text { POF[1] } \\
\text { poorest }\end{array}$ & 10.7 & 0.9617 & 0.7334 & 0.1122 & 0.0856 & 0.0715 \\
\hline POF[2] & 8.0 & 0.7657 & 0.3047 & 0.0716 & 0.0285 & 0.0135 \\
\hline POF[3] & 16.0 & 0.5355 & 0.1496 & 0.0877 & 0.0245 & 0.0092 \\
\hline POF[4] & 7.3 & 0.2837 & 0.0539 & 0.0202 & 0.0038 & 0.0011 \\
\hline POF[5] & 11.0 & 0.1143 & 0.0189 & 0.0122 & 0.0020 & 0.0005 \\
\hline POF[6] & 7.9 & 0.0390 & 0.0054 & 0.0029 & 0.0004 & 0.0001 \\
\hline POF[7] & 12.9 & 0.0082 & 0.0009 & 0.0010 & 0.0001 & 0.0000 \\
\hline POF[8] & 7.5 & 0.0008 & 0.0001 & 0.0001 & 0.0000 & 0.0000 \\
\hline POF[9] & 7.7 & 0.0000 & 0.0000 & 0.0000 & 0.0000 & 0.0000 \\
\hline \multirow[t]{2}{*}{$\begin{array}{c}\text { POF[10] } \\
\text { richest }\end{array}$} & 10.9 & 0.0000 & 0.0000 & 0.0000 & 0.0000 & 0.0000 \\
\hline & $=100$ & $\begin{array}{c}\text { FGT0 }= \\
\text { ave }=0.3079\end{array}$ & $\begin{array}{c}\text { FGT1 }= \\
\text { ave }=0.1449\end{array}$ & $\begin{array}{c}\text { FGT0 }= \\
\text { sum }=0.3079\end{array}$ & $\begin{array}{c}\text { FGT1 }= \\
\text { sum }=0.1449\end{array}$ & $\begin{array}{c}\text { FGT2 }= \\
\text { sum }=0.0960\end{array}$ \\
\hline
\end{tabular}

FGT0: the proportion of poor households below the poverty line; FGT1: the average poverty gap; FGT2: extent of inequality among the poor. 
Table 3. Regional poverty and income inequality figures. Brazil, 2001.

\begin{tabular}{lccccc}
\hline \multicolumn{1}{c}{ Regions } & Macro- & Population share $\begin{array}{c}\text { Proportion of } \\
\text { poouseholds } \\
\text { regions* }\end{array}$ & $\begin{array}{c}\text { Regional } \\
\text { in regional } \\
\text { of each region } \\
\text { the Poverty } \\
\text { population }\end{array}$ & $\begin{array}{c}\text { Regional } \\
\text { Average } \\
\text { Poverty } \\
\text { Gap }\end{array}$ \\
\hline 1 Rondonia & $\mathrm{N}$ & 0.005 & 0.338 & 0.001 & 0.147 \\
2 Acre & $\mathrm{N}$ & 0.002 & 0.356 & 0.000 & 0.176 \\
3 Amazonas & $\mathrm{N}$ & 0.011 & 0.396 & 0.002 & 0.196 \\
4 Roraima & $\mathrm{N}$ & 0.001 & 0.347 & 0.000 & 0.152 \\
5 Para & $\mathrm{N}$ & 0.023 & 0.425 & 0.005 & 0.194 \\
6 Amapa & $\mathrm{N}$ & 0.003 & 0.151 & 0.000 & 0.069 \\
7 Tocantins & $\mathrm{N}$ & 0.006 & 0.429 & 0.001 & 0.180 \\
8 Maranhao & $\mathrm{NE}$ & 0.029 & 0.579 & 0.008 & 0.288 \\
9 Piaui & $\mathrm{NE}$ & 0.015 & 0.564 & 0.005 & 0.304 \\
10 Ceara & $\mathrm{NE}$ & 0.042 & 0.540 & 0.011 & 0.267 \\
11 RGNorte & $\mathrm{NE}$ & 0.016 & 0.471 & 0.004 & 0.218 \\
12 Paraiba & $\mathrm{NE}$ & 0.019 & 0.550 & 0.005 & 0.257 \\
13 Pernambuco & $\mathrm{NE}$ & 0.045 & 0.512 & 0.011 & 0.248 \\
14 Alagoas & $\mathrm{NE}$ & 0.015 & 0.577 & 0.004 & 0.289 \\
15 Sergipe & $\mathrm{NE}$ & 0.010 & 0.503 & 0.002 & 0.239 \\
16 Bahia & $\mathrm{NE}$ & 0.073 & 0.520 & 0.019 & 0.256 \\
17 MinasG & $\mathrm{SE}$ & 0.108 & 0.301 & 0.014 & 0.133 \\
18 EspSanto & $\mathrm{SE}$ & 0.019 & 0.324 & 0.003 & 0.144 \\
19 RioJaneiro & $\mathrm{SE}$ & 0.095 & 0.202 & 0.009 & 0.095 \\
20 SaoPaulo & $\mathrm{SE}$ & 0.229 & 0.166 & 0.019 & 0.083 \\
21 Parana & $\mathrm{S}$ & 0.059 & 0.237 & 0.006 & 0.100 \\
22 StaCatari & $\mathrm{S}$ & 0.034 & 0.136 & 0.002 & 0.055 \\
23 RGSul & $\mathrm{S}$ & 0.067 & 0.179 & 0.005 & 0.073 \\
24 MtGrSul & $\mathrm{CW}$ & 0.013 & 0.289 & 0.002 & 0.120 \\
25 MtGrosso & $\mathrm{CW}$ & 0.015 & 0.251 & 0.002 & 0.106 \\
26 Goias & $\mathrm{CW}$ & 0.031 & 0.300 & 0.004 & 0.126 \\
27 DF & $\mathrm{CW}$ & 0.013 & 0.219 & 0.001 & 0.106 \\
\hline \multicolumn{1}{c}{ Total } & $\mathrm{Brazil}$ & 1.000 & 0.308 & 0.145 & 0.145 \\
\hline
\end{tabular}

*Macro-Regions: N = North; NE = North-East; SE = South-East; S = South; CW = Center-West 
Table 4. Share (\%) of occupations in each activity's labor bill.

\begin{tabular}{|c|c|c|c|c|c|c|c|c|c|c|c|}
\hline \multicolumn{12}{|c|}{ OCCUPATIONS (WAGE CLASS) } \\
\hline Sectors & 1 & 2 & 3 & 4 & 5 & 6 & 7 & 8 & 9 & 10 & Total \\
\hline Agriculture & 40.5 & 30.2 & 5.8 & 6.0 & 5.2 & 3.3 & 3.7 & 1.8 & 1.9 & 1.6 & 100 \\
\hline MineralExtr & 12.0 & 19.4 & 6.8 & 6.9 & 8.4 & 6.1 & 12.8 & 9.9 & 10.8 & 6.9 & 100 \\
\hline PetrGasExtr & 0.0 & 0.0 & 0.0 & 0.9 & 0.9 & 6.1 & 16.1 & 12.1 & 22.8 & 41.1 & 100 \\
\hline MinNonMet & 7.1 & 18.8 & 7.4 & 8.9 & 11.5 & 11.8 & 14.1 & 7.6 & 7.4 & 5.3 & 100 \\
\hline IronProduc & 1.9 & 6.8 & 4.0 & 6.3 & 10.2 & 9.7 & 22.7 & 14.0 & 15.4 & 9.1 & 100 \\
\hline MetalNonFerr & 1.9 & 6.8 & 4.0 & 6.3 & 10.2 & 9.7 & 22.7 & 14.0 & 15.4 & 9.1 & 100 \\
\hline OtherMetal & 1.9 & 6.8 & 4.0 & 6.3 & 10.2 & 9.7 & 22.7 & 14.0 & 15.4 & 9.1 & 100 \\
\hline MachTractor & 0.5 & 4.6 & 1.9 & 4.8 & 6.8 & 9.0 & 19.6 & 17.2 & 16.8 & 18.8 & 100 \\
\hline EletricMat & 0.4 & 3.8 & 2.6 & 3.3 & 10.3 & 11.6 & 20.4 & 15.5 & 17.0 & 15.1 & 100 \\
\hline EletronEquip & 0.4 & 3.8 & 2.6 & 3.3 & 10.3 & 11.6 & 20.4 & 15.5 & 17.0 & 15.1 & 100 \\
\hline Automobiles & 0.3 & 2.5 & 1.0 & 2.4 & 7.7 & 8.6 & 19.6 & 15.7 & 22.4 & 19.8 & 100 \\
\hline OthVeicSpare & 0.3 & 2.5 & 1.0 & 2.4 & 7.7 & 8.6 & 19.6 & 15.7 & 22.4 & 19.8 & 100 \\
\hline WoodFurnit & 8.2 & 11.7 & 6.6 & 8.8 & 12.4 & 11.9 & 16.6 & 9.3 & 9.6 & 5.0 & 100 \\
\hline PaperGraph & 2.3 & 7.8 & 3.7 & 6.2 & 8.4 & 8.1 & 18.7 & 13.0 & 16.7 & 15.1 & 100 \\
\hline RubberInd & 0.8 & 4.7 & 3.2 & 4.6 & 14.4 & 5.5 & 24.0 & 13.6 & 16.6 & 12.5 & 100 \\
\hline ChemicElem & 2.1 & 7.8 & 3.0 & 4.2 & 9.1 & 11.8 & 14.2 & 15.6 & 16.4 & 15.8 & 100 \\
\hline PetrolRefin & 0.5 & 1.5 & 2.7 & 0.3 & 9.0 & 5.7 & 13.1 & 7.2 & 10.5 & 49.5 & 100 \\
\hline VariousChem & 0.0 & 6.8 & 9.6 & 13.4 & 25.3 & 0.0 & 14.5 & 2.8 & 7.9 & 19.7 & 100 \\
\hline PharmacPerf & 1.7 & 5.7 & 3.1 & 6.8 & 4.1 & 7.5 & 13.5 & 11.3 & 18.7 & 27.4 & 100 \\
\hline Plastics & 1.6 & 6.3 & 2.3 & 8.5 & 12.8 & 12.1 & 24.6 & 10.3 & 9.0 & 12.6 & 100 \\
\hline Textiles & 14.7 & 9.0 & 4.9 & 7.2 & 12.5 & 11.0 & 17.6 & 11.3 & 6.2 & 5.5 & 100 \\
\hline Apparel & 3.2 & 17.3 & 7.5 & 15.1 & 16.1 & 9.7 & 15.7 & 5.4 & 4.5 & 5.5 & 100 \\
\hline ShoesInd & 4.1 & 16.2 & 6.5 & 13.5 & 18.2 & 13.0 & 14.4 & 5.7 & 4.8 & 3.6 & 100 \\
\hline CoffeeInd & 8.6 & 14.3 & 6.1 & 9.6 & 13.2 & 11.3 & 15.1 & 8.3 & 7.4 & 6.0 & 100 \\
\hline VegetProcess & 8.6 & 14.3 & 6.1 & 9.6 & 13.2 & 11.3 & 15.1 & 8.3 & 7.4 & 6.0 & 100 \\
\hline Slaughter & 8.6 & 14.3 & 6.1 & 9.6 & 13.2 & 11.3 & 15.1 & 8.3 & 7.4 & 6.0 & 100 \\
\hline Dairy & 8.6 & 14.3 & 6.1 & 9.6 & 13.2 & 11.3 & 15.1 & 8.3 & 7.4 & 6.0 & 100 \\
\hline SugarInd & 8.6 & 14.3 & 6.1 & 9.6 & 13.2 & 11.3 & 15.1 & 8.3 & 7.4 & 6.0 & 100 \\
\hline VegetOils & 8.6 & 14.3 & 6.1 & 9.6 & 13.2 & 11.3 & 15.1 & 8.3 & 7.4 & 6.0 & 100 \\
\hline OthFood & 8.6 & 14.3 & 6.1 & 9.6 & 13.2 & 11.3 & 15.1 & 8.3 & 7.4 & 6.0 & 100 \\
\hline VariousInd & 16.8 & 13.4 & 6.6 & 6.2 & 11.4 & 7.4 & 13.1 & 7.8 & 10.7 & 6.5 & 100 \\
\hline PubUtilServ & 1.7 & 17.5 & 5.3 & 8.6 & 7.1 & 6.0 & 12.9 & 12.2 & 14.2 & 14.5 & 100 \\
\hline CivilConst & 6.3 & 13.4 & 8.6 & 10.1 & 12.5 & 9.0 & 20.2 & 9.6 & 6.9 & 3.4 & 100 \\
\hline Trade & 10.0 & 14.2 & 6.6 & 8.2 & 10.7 & 8.2 & 15.1 & 8.3 & 10.0 & 8.7 & 100 \\
\hline Transport & 4.6 & 7.0 & 4.4 & 4.7 & 7.5 & 7.1 & 19.0 & 16.1 & 18.1 & 11.6 & 100 \\
\hline Comunic & 1.4 & 4.6 & 2.4 & 5.1 & 7.9 & 9.4 & 18.6 & 13.9 & 17.2 & 19.4 & 100 \\
\hline FinancInst & 0.9 & 3.5 & 1.3 & 3.5 & 6.6 & 4.2 & 10.0 & 11.8 & 23.3 & 34.9 & 100 \\
\hline FamServic & 16.4 & 20.3 & 7.4 & 8.4 & 9.6 & 6.8 & 12.1 & 6.5 & 7.2 & 5.4 & 100 \\
\hline EnterpServ & 2.9 & 8.1 & 4.3 & 5.7 & 8.1 & 6.4 & 13.0 & 8.6 & 15.7 & 27.2 & 100 \\
\hline BuildRentals & 2.0 & 4.3 & 2.7 & 4.8 & 9.9 & 6.3 & 17.1 & 8.8 & 18.4 & 25.7 & 100 \\
\hline PublAdm & 1.7 & 13.1 & 3.6 & 7.2 & 7.6 & 6.8 & 13.0 & 12.1 & 19.3 & 15.6 & 100 \\
\hline NMercPriSer & 7.6 & 16.6 & 6.0 & 9.2 & 9.3 & 10.9 & 13.7 & 8.2 & 11.6 & 6.9 & 100 \\
\hline
\end{tabular}


Table 5. Share of each activity in total labor bill, by occupation.

\begin{tabular}{|c|c|c|c|c|c|c|c|c|c|c|}
\hline \multirow[b]{2}{*}{ Sectors } & \multicolumn{10}{|c|}{ OCCUPATIONS (WAGE CLASS) } \\
\hline & 1 & 2 & 3 & 4 & 5 & 6 & 7 & 8 & 9 & 10 \\
\hline$\overline{\text { Agriculture }}$ & 41.0 & 17.8 & 9.8 & 6.9 & 4.8 & 3.8 & 2.2 & 1.4 & 1.1 & 0.9 \\
\hline MineralExtr & 0.5 & 0.4 & 0.4 & 0.3 & 0.3 & 0.3 & 0.3 & 0.3 & 0.2 & 0.1 \\
\hline PetrGasExtr & 0.0 & 0.0 & 0.0 & 0.0 & 0.0 & 0.1 & 0.2 & 0.2 & 0.3 & 0.5 \\
\hline MinNonMet & 0.5 & 0.8 & 0.9 & 0.8 & 0.8 & 1.0 & 0.6 & 0.5 & 0.3 & 0.2 \\
\hline IronProduc & 0.1 & 0.1 & 0.2 & 0.2 & 0.3 & 0.3 & 0.4 & 0.3 & 0.3 & 0.2 \\
\hline MetalNonFerr & 0.0 & 0.1 & 0.1 & 0.1 & 0.2 & 0.2 & 0.2 & 0.2 & 0.1 & 0.1 \\
\hline OtherMetal & 0.3 & 0.7 & 1.2 & 1.3 & 1.7 & 1.9 & 2.4 & 2.0 & 1.5 & 0.9 \\
\hline MachTractor & 0.1 & 0.5 & 0.5 & 0.9 & 1.1 & 1.7 & 2.0 & 2.3 & 1.6 & 1.8 \\
\hline EletricMat & 0.0 & 0.1 & 0.2 & 0.2 & 0.5 & 0.7 & 0.7 & 0.7 & 0.5 & 0.5 \\
\hline EletronEquip & 0.0 & 0.1 & 0.2 & 0.2 & 0.4 & 0.6 & 0.5 & 0.5 & 0.4 & 0.4 \\
\hline Automobiles & 0.0 & 0.1 & 0.1 & 0.1 & 0.3 & 0.4 & 0.5 & 0.5 & 0.5 & 0.5 \\
\hline OthVeicSpare & 0.0 & 0.2 & 0.2 & 0.3 & 0.8 & 1.1 & 1.3 & 1.3 & 1.4 & 1.2 \\
\hline WoodFurnit & 0.9 & 0.7 & 1.1 & 1.0 & 1.2 & 1.4 & 1.0 & 0.8 & 0.6 & 0.3 \\
\hline PaperGraph & 0.3 & 0.6 & 0.8 & 0.9 & 1.0 & 1.2 & 1.4 & 1.3 & 1.2 & 1.1 \\
\hline RubberInd & 0.0 & 0.1 & 0.1 & 0.1 & 0.3 & 0.1 & 0.3 & 0.2 & 0.2 & 0.1 \\
\hline ChemicElem & 0.1 & 0.1 & 0.2 & 0.1 & 0.3 & 0.4 & 0.3 & 0.4 & 0.3 & 0.3 \\
\hline PetrolRefin & 0.0 & 0.1 & 0.3 & 0.0 & 0.5 & 0.4 & 0.5 & 0.3 & 0.4 & 1.7 \\
\hline VariousChem & 0.0 & 0.3 & 1.1 & 1.0 & 1.6 & 0.0 & 0.6 & 0.2 & 0.3 & 0.8 \\
\hline $\begin{array}{l}\text { PharmacPerf } \\
\text {. }\end{array}$ & 0.1 & 0.2 & 0.3 & 0.4 & 0.2 & 0.5 & 0.5 & 0.5 & 0.6 & 0.9 \\
\hline Plastics & 0.1 & 0.2 & 0.2 & 0.5 & 0.6 & 0.7 & 0.8 & 0.4 & 0.3 & 0.4 \\
\hline Textiles & 0.7 & 0.2 & 0.4 & 0.4 & 0.5 & 0.6 & 0.5 & 0.4 & 0.2 & 0.1 \\
\hline Apparel & 0.3 & 0.9 & 1.1 & 1.5 & 1.3 & 1.0 & 0.8 & 0.4 & 0.2 & 0.3 \\
\hline ShoesInd & 0.2 & 0.4 & 0.4 & 0.6 & 0.7 & 0.6 & 0.3 & 0.2 & 0.1 & 0.1 \\
\hline CoffeeInd & 0.1 & 0.1 & 0.1 & 0.1 & 0.1 & 0.1 & 0.1 & 0.1 & 0.0 & 0.0 \\
\hline VegetProcess & 0.5 & 0.4 & 0.5 & 0.6 & 0.6 & 0.7 & 0.5 & 0.3 & 0.2 & 0.2 \\
\hline Slaughter & 0.4 & 0.3 & 0.4 & 0.5 & 0.5 & 0.5 & 0.4 & 0.3 & 0.2 & 0.1 \\
\hline Dairy & 0.1 & 0.1 & 0.1 & 0.2 & 0.2 & 0.2 & 0.1 & 0.1 & 0.1 & 0.0 \\
\hline SugarInd & 0.2 & 0.2 & 0.2 & 0.2 & 0.2 & 0.2 & 0.2 & 0.1 & 0.1 & 0.1 \\
\hline VegetOils & 0.1 & 0.1 & 0.1 & 0.1 & 0.1 & 0.1 & 0.1 & 0.1 & 0.0 & 0.0 \\
\hline OthFood & 1.0 & 1.0 & 1.2 & 1.2 & 1.4 & 1.5 & 1.0 & 0.7 & 0.5 & 0.4 \\
\hline VariousInd & 0.7 & 0.3 & 0.5 & 0.3 & 0.5 & 0.4 & 0.3 & 0.3 & 0.3 & 0.2 \\
\hline PubUtilServ & 0.5 & 3.2 & 2.8 & 3.0 & 2.0 & 2.1 & 2.4 & 3.0 & 2.5 & 2.6 \\
\hline CivilConst & 2.7 & 3.3 & 6.1 & 4.8 & 4.9 & 4.3 & 5.0 & 3.2 & 1.6 & 0.8 \\
\hline Trade & 13.5 & 11.2 & 14.8 & 12.6 & 13.3 & 12.5 & 12.0 & 8.7 & 7.5 & 6.6 \\
\hline Transport & 2.6 & 2.3 & 4.1 & 3.0 & 3.8 & 4.4 & 6.2 & 7.0 & 5.6 & 3.6 \\
\hline Comunic & 0.2 & 0.4 & 0.6 & 0.8 & 1.0 & 1.5 & 1.6 & 1.6 & 1.4 & 1.6 \\
\hline FinancInst & 1.0 & 2.3 & 2.4 & 4.4 & 6.9 & 5.3 & 6.7 & 10.5 & 14.6 & 22.3 \\
\hline FamServic & 21.0 & 15.1 & 15.8 & 12.1 & 11.2 & 9.8 & 9.0 & 6.5 & 5.1 & 3.9 \\
\hline EnterpServ & 1.6 & 2.6 & 4.0 & 3.6 & 4.1 & 4.0 & 4.2 & 3.8 & 4.8 & 8.5 \\
\hline BuildRentals & 0.1 & 0.2 & 0.3 & 0.3 & 0.6 & 0.4 & 0.6 & 0.4 & 0.6 & 0.9 \\
\hline PublAdm & 6.4 & 29.4 & 23.3 & 31.2 & 26.7 & 29.3 & 29.2 & 36.3 & 40.8 & 33.7 \\
\hline NMercPriSer & 2.2 & 2.8 & 2.9 & 3.0 & 2.4 & 3.5 & 2.3 & 1.8 & 1.8 & 1.1 \\
\hline Total & 100.0 & 100.0 & 100.0 & 100.0 & 100.0 & 100.0 & 100.0 & 100.0 & 100.0 & 100.0 \\
\hline
\end{tabular}


Table 6. Wage bill distribution according to occupational wages and household income classes. 1996 million Reais.

\begin{tabular}{lrrrrrrrrrrrr}
\hline $\begin{array}{c}\text { Household } \\
\text { Income } \\
\text { Classes }\end{array}$ & \multicolumn{10}{c}{ OCCUPATIONAL WAGES CLASSES (personal) } \\
\cline { 2 - 8 } & OCC1 & OCC2 & OCC3 & OCC4 & OCC5 & OCC6 & OCC7 & OCC8 & OCC9 & OCC10 & Total \\
\hline POF[1] & 1531 & 1637 & 0 & 0 & 0 & 0 & 0 & 0 & 0 & 0 & 3168 \\
POF[2] & 538 & 2409 & 1632 & 783 & 0 & 0 & 0 & 0 & 0 & 0 & 5362 \\
POF[3] & 1804 & 3996 & 1201 & 2460 & 4327 & 3728 & 342 & 0 & 0 & 0 & 17859 \\
POF[4] & 766 & 1513 & 861 & 1380 & 1077 & 616 & 5020 & 0 & 0 & 0 & 11233 \\
POF[5] & 932 & 2787 & 1147 & 1649 & 2746 & 2254 & 5945 & 3526 & 0 & 0 & 20985 \\
POF[6] & 537 & 1811 & 795 & 1410 & 2133 & 2127 & 4305 & 5517 & 405 & 0 & 19039 \\
POF[7] & 576 & 2315 & 1178 & 2012 & 3038 & 3102 & 8717 & 7654 & 12773 & 0 & 41365 \\
POF[8] & 201 & 1137 & 524 & 1045 & 1819 & 1969 & 4896 & 5585 & 13211 & 1427 & 31814 \\
POF[9] & 123 & 695 & 401 & 762 & 1312 & 1449 & 4571 & 5218 & 15864 & 16994 & 47388 \\
POF[10] & 83 & 527 & 301 & 576 & 1135 & 1185 & 3939 & 5086 & 18480 & 134499 & 165811 \\
\hline Total & 7091 & 18827 & 8040 & 12077 & 17586 & 16430 & 37734 & 32586 & 60732 & 152920 & 364024 \\
\hline
\end{tabular}


Table 7. Brazilian external trade structure.

\begin{tabular}{|c|c|c|c|c|c|c|c|}
\hline & \multicolumn{5}{|c|}{ EXTERNAL TRADE } & \multicolumn{2}{|c|}{ PRODUCTION } \\
\hline & $\begin{array}{l}\text { Armington } \\
\text { Elasticities }\end{array}$ & $\begin{array}{l}\text { Share in } \\
\text { total Brazilian } \\
\text { exports }\end{array}$ & $\begin{array}{c}\text { Exported } \\
\text { share of } \\
\text { total output }\end{array}$ & $\begin{array}{c}\text { Import share } \\
\text { in local } \\
\text { markets }\end{array}$ & $\begin{array}{l}\text { Share in } \\
\text { total } \\
\text { imports }\end{array}$ & $\begin{array}{l}\text { Capital/ } \\
\text { Labor } \\
\text { ratio }\end{array}$ & $\begin{array}{c}\text { Value added/ } \\
\text { value of } \\
\text { production }\end{array}$ \\
\hline Coffee & 2.38 & 0 & 0 & 0 & 0 & 0.64 & 0.61 \\
\hline SugarCane & 2.2 & 0 & 0 & 0 & 0 & 0.64 & 0.61 \\
\hline PaddyRice & 2.2 & 0 & 0 & 0.02 & 0.001 & 0.64 & 0.61 \\
\hline Wheat & 2.2 & 0 & 0 & 0.68 & 0.020 & 0.64 & 0.61 \\
\hline Soybean & 2.2 & 0.019 & 0.170 & 0.06 & 0.004 & 0.64 & 0.61 \\
\hline Cotton & 2.2 & 0 & 0 & 0.02 & 0 & 0.64 & 0.61 \\
\hline Corn & 2.2 & 0.001 & 0.015 & 0.01 & 0.001 & 0.64 & 0.61 \\
\hline Livestock & 2.8 & 0 & 0 & 0.01 & 0.001 & 0.64 & 0.61 \\
\hline NaturMilk & 2.2 & 0 & 0 & 0 & 0 & 0.64 & 0.61 \\
\hline Poultry & 2.8 & 0 & 0.002 & 0.01 & 0 & 0.64 & 0.61 \\
\hline OtherAgric & 2.38 & 0.022 & 0.019 & 0.02 & 0.015 & 0.64 & 0.61 \\
\hline MineralExtr & 2.8 & 0.059 & 0.398 & 0.09 & 0.006 & 0.44 & 0.28 \\
\hline PetrGasExtr & 2.8 & 0 & 0.002 & 0.41 & 0.063 & 4.19 & 0.51 \\
\hline MinNonMet & 2.8 & 0.014 & 0.033 & 0.04 & 0.009 & 1.58 & 0.38 \\
\hline IronProduc & 2.8 & 0.073 & 0.154 & 0.03 & 0.009 & 2.99 & 0.18 \\
\hline MetalNonFerr & 2.8 & 0.041 & 0.196 & 0.1 & 0.014 & 2.99 & 0.23 \\
\hline OtherMetal & 2.8 & 0.018 & 0.037 & 0.06 & 0.018 & 0.32 & 0.36 \\
\hline MachTractor & 5.2 & 0.038 & 0.077 & 0.22 & 0.088 & 1.53 & 0.56 \\
\hline EletricMat & 2.8 & 0.027 & 0.086 & 0.19 & 0.040 & 0.86 & 0.27 \\
\hline EletronEquip & 2.8 & 0.018 & 0.047 & 0.36 & 0.123 & 3.04 & 0.38 \\
\hline Automobiles & 5.2 & 0.029 & 0.057 & 0.1 & 0.034 & 2.60 & 0.25 \\
\hline OthVeicSpare & 5.2 & 0.068 & 0.144 & 0.2 & 0.057 & 0.69 & 0.30 \\
\hline WoodFurnit & 2.8 & 0.026 & 0.078 & 0.02 & 0.004 & 0.66 & 0.40 \\
\hline PaperGraph & 1.8 & 0.032 & 0.067 & 0.06 & 0.018 & 0.45 & 0.28 \\
\hline RubberInd & 1.9 & 0.012 & 0.071 & 0.1 & 0.010 & 2.41 & 0.32 \\
\hline ChemicElem & 1.9 & 0.016 & 0.066 & 0.15 & 0.032 & 3.61 & 0.35 \\
\hline PetrolRefin & 1.9 & 0.031 & 0.034 & 0.11 & 0.083 & 6.08 & 0.31 \\
\hline VariousChem & 1.9 & 0.015 & 0.039 & 0.1 & 0.028 & 1.11 & 0.28 \\
\hline PharmacPerf & 1.9 & 0.007 & 0.021 & 0.15 & 0.028 & 1.84 & 0.46 \\
\hline Plastics & 1.9 & 0.004 & 0.021 & 0.07 & 0.010 & 1.46 & 0.43 \\
\hline Textiles & 2.2 & 0.020 & 0.052 & 0.11 & 0.031 & 1.98 & 0.26 \\
\hline Apparel & 4.4 & 0.003 & 0.011 & 0.03 & 0.005 & 0.37 & 0.38 \\
\hline ShoesInd & 4.4 & 0.043 & 0.294 & 0.10 & 0.006 & 0.71 & 0.35 \\
\hline CoffeeInd & 3.1 & 0.033 & 0.237 & 0 & 0 & 2.64 & 0.21 \\
\hline VegetProcess & 2.2 & 0.058 & 0.105 & 0.04 & 0.012 & 1.69 & 0.22 \\
\hline Slaughter & 2.2 & 0.025 & 0.055 & 0.02 & 0.004 & 1.45 & 0.19 \\
\hline Dairy & 2.2 & 0.001 & 0.003 & 0.05 & 0.007 & 2.99 & 0.22 \\
\hline SugarInd & 2.2 & 0.029 & 0.217 & 0 & 0 & 0.32 & 0.16 \\
\hline VegetOils & 2.2 & 0.065 & 0.229 & 0.04 & 0.006 & 2.72 & 0.11 \\
\hline
\end{tabular}




\begin{tabular}{lccccccc}
\hline & \multicolumn{3}{c}{ EXTERNAL TRADE } & \multicolumn{2}{c}{ PRODUCTION } \\
\hline & $\begin{array}{l}\text { Armington } \\
\text { Elasticities }\end{array}$ & $\begin{array}{c}\text { Share in } \\
\text { total Brazilian } \\
\text { exports }\end{array}$ & $\begin{array}{c}\text { Exported } \\
\text { share of } \\
\text { total output }\end{array}$ & $\begin{array}{c}\text { Import share } \\
\text { in local } \\
\text { markets }\end{array}$ & $\begin{array}{c}\text { Share in } \\
\text { total } \\
\text { imports }\end{array}$ & $\begin{array}{c}\text { Capital/ } \\
\text { Labor } \\
\text { ratio }\end{array}$ & $\begin{array}{c}\text { Value added/ } \\
\text { value of } \\
\text { production }\end{array}$ \\
\hline OthFood & 2.2 & 0.022 & 0.029 & 0.05 & 0.020 & 1.03 & 0.27 \\
VariousInd & 2.8 & 0.010 & 0.049 & 0.22 & 0.028 & 1.22 & 0.43 \\
PubUtilServ & 1.9 & 0 & 0 & 0.03 & 0.014 & 0.91 & 0.59 \\
CivilConst & 1.9 & 0 & 0 & 0 & 0 & 4.06 & 0.66 \\
Trade & 1.9 & 0.009 & 0.016 & 0.01 & 0.011 & 0.18 & 0.53 \\
Transport & 1.9 & 0.053 & 0.084 & 0.04 & 0.022 & 0.19 & 0.49 \\
Comunic & 1.9 & 0.005 & 0.014 & 0.01 & 0.003 & 1.97 & 0.78 \\
FinancInst & 1.9 & 0.007 & 0.006 & 0.01 & 0.006 & 0.23 & 0.64 \\
FamServic & 1.9 & 0.016 & 0.010 & 0.05 & 0.067 & 0.36 & 0.67 \\
EnterpServ & 2.1 & 0.019 & 0.027 & 0.05 & 0.029 & 0.52 & 0.72 \\
BuildRentals & 1.9 & 0 & 0 & 0 & 0 & 51.56 & 0.95 \\
PublAdm & 1.9 & 0.010 & 0.003 & 0.01 & 0.012 & 0.00 & 0.73 \\
NMercPriSer & 2.1 & 0 & 0 & 0 & 0 & 0.01 & 0.93 \\
\hline
\end{tabular}


Table 8. Shocks to the CGE model.

\begin{tabular}{|c|c|c|c|c|c|c|}
\hline & \multicolumn{2}{|c|}{ Import Tariffs } & \multicolumn{2}{|c|}{$\begin{array}{l}\text { Import CIF } \\
\text { Prices }\end{array}$} & \multicolumn{2}{|c|}{$\begin{array}{l}\text { Implied Export Price } \\
\text { Shift* }\end{array}$} \\
\hline & Doha & Full-lib & Doha & Full-lib & Doha & Full-lib \\
\hline Coffee & -0.04 & -6.43 & 0.74 & 1.92 & -0.74 & -0.73 \\
\hline SugarCane & 0 & -4.99 & 1.02 & 1.80 & 7.73 & 9.65 \\
\hline PaddyRice & 0 & -0.17 & 2.8 & 6.47 & 7.58 & 38.41 \\
\hline Wheat & 0 & -0.12 & 1.95 & 8.49 & 0.94 & -1.80 \\
\hline Soybean & 0 & -0.09 & 2.54 & 5.92 & 3.90 & 15.49 \\
\hline Cotton & 0 & -5.55 & 2.45 & 4.26 & 5.37 & 18.13 \\
\hline Corn & 0 & -0.55 & 2.41 & 7.56 & 6.32 & 25.24 \\
\hline Livestock & 0 & -0.37 & 1.05 & 2.40 & 0.24 & -4.50 \\
\hline NaturMilk & 0 & 0 & 0.73 & -0.26 & -1.11 & -9.08 \\
\hline Poultry & 0 & -4.53 & 0.45 & 1.9 & 0.47 & 0.39 \\
\hline OtherAgric & -0.04 & -6.43 & 0.74 & 1.92 & -0.74 & -0.73 \\
\hline MineralExtr & 0 & -2.95 & 0.16 & 0.12 & 0.48 & 1.40 \\
\hline PetrGasExtr & 0 & 0 & 0.14 & 0.6 & 0.20 & 1.70 \\
\hline MinNonMet & -0.01 & -9.82 & 0.13 & 0.26 & 0.78 & 2.76 \\
\hline IronProduc & -0.07 & -10.72 & 0.04 & 0.19 & 0.25 & 0.88 \\
\hline MetalNonFerr & -0.23 & -7.57 & 0.03 & -0.27 & 0.80 & 1.70 \\
\hline OtherMetal & -0.04 & -14.25 & -0.01 & 0.13 & 0.45 & 1.76 \\
\hline MachTractor & -0.02 & -2.59 & -0.17 & -0.27 & -0.09 & -0.45 \\
\hline EletricMat & -0.1 & -10.92 & -0.02 & 0.05 & 0.19 & 0.36 \\
\hline EletronEquip & -0.01 & -10.84 & 0 & 0.05 & 0.28 & 0.67 \\
\hline Automobiles & -2.14 & -16.91 & 0.24 & -0.16 & 0.53 & 5.13 \\
\hline OthVeicSpare & -0.02 & -2.59 & -0.17 & -0.27 & -0.09 & -0.45 \\
\hline WoodFurnit & -0.84 & -11.81 & 0.06 & 0.24 & 0.49 & 1.54 \\
\hline PaperGraph & 0 & -8.54 & 0 & -0.04 & 0.21 & 0.28 \\
\hline RubberInd & -0.28 & -7.98 & 0 & -0.25 & 0.35 & 0.30 \\
\hline ChemicElem & -0.28 & -7.98 & 0 & -0.25 & 0.35 & 0.30 \\
\hline PetrolRefin & 0 & -0.41 & 0.14 & -0.31 & 0.45 & 2.65 \\
\hline VariousChem & -0.28 & -7.98 & 0 & -0.25 & 0.35 & 0.30 \\
\hline PharmacPerf & -0.28 & -7.98 & 0 & -0.25 & 0.35 & 0.30 \\
\hline Plastics & -0.28 & -7.98 & 0 & -0.25 & 0.35 & 0.30 \\
\hline Textiles & 0 & -13.6 & 0.65 & 0.33 & 1.34 & 0.79 \\
\hline Apparel & 0 & -17.18 & 1.00 & 0.25 & 1.46 & -0.67 \\
\hline ShoesInd & -0.14 & -11.64 & 0.43 & 0.21 & 0.26 & -0.32 \\
\hline CoffeeInd & -0.05 & -16.54 & 0.25 & 0.2 & 1.50 & 1.66 \\
\hline VegetProcess & -0.21 & -7.66 & 0.74 & 0.46 & 2.20 & 10.32 \\
\hline Slaughter & 0 & -4.02 & 2.17 & 2.91 & 18.02 & 38.79 \\
\hline Dairy & -0.02 & -6.39 & 4.43 & 6.74 & 7.56 & 15.41 \\
\hline
\end{tabular}




\begin{tabular}{llccccc}
\hline & \multicolumn{2}{c}{ Import Tariffs } & \multicolumn{2}{c}{$\begin{array}{c}\text { Import CIF } \\
\text { Prices }\end{array}$} & \multicolumn{2}{c}{ Implied Export Price } \\
& Doha & Full-lib & Doha & Full-lib & Doha & Full-lib \\
\hline SugarInd & 0 & -13.18 & 5.22 & 5.93 & 4.30 & 14.73 \\
VegetOils & 0 & -7.18 & 0.88 & 3.39 & 3.50 & -0.70 \\
OthFood & -0.21 & -7.66 & 0.74 & 0.46 & 2.20 & 10.32 \\
VariousInd & -0.05 & -15.39 & 0.05 & 0.1 & 0.11 & -0.15 \\
PubUtilServ & 0 & 0 & -0.05 & 0.07 & -0.08 & -0.32 \\
CivilConst & 0 & 0 & 0.03 & 0.15 & -0.03 & 0.02 \\
Trade & 0 & 0 & 0.05 & 0.89 & 0.01 & 0.52 \\
Transport & 0 & 0 & -0.01 & 0.3 & 0.03 & 0.51 \\
Comunic & 0 & 0 & -0.03 & 0.4 & -0.06 & 0.03 \\
FinancInst & 0 & 0 & -0.07 & 0.38 & -0.10 & -0.01 \\
FamServic & 0 & 0 & -0.10 & 0.21 & -0.11 & -0.01 \\
EnterpServ & 0 & 0 & -0.06 & 0.29 & -0.04 & 0.16 \\
BuildRentals & 0 & 0 & 2.53 & 7.76 & 2.69 & 8.29 \\
PublAdm & 0 & 0 & -0.05 & 0.07 & -0.08 & -0.32 \\
NMercPriSer & 0 & 0 & -0.10 & 0.21 & -0.11 & -0.01 \\
\hline
\end{tabular}

* Vertical shift in export demand schedule calculated from GTAP results. 
Table 9. Selected macroeconomic results.

\begin{tabular}{lcc}
\hline \multicolumn{1}{c}{ Macros (percentage changes) } & \multicolumn{2}{c}{ Scenarios } \\
\hline Real Household Consumption & Doha & Full-lib \\
Real Investment & 0.22 & 0.61 \\
Real Government Expenditure & 0.00 & 0.00 \\
Exports Volume & 0.00 & 0.00 \\
Imports Volume & 0.91 & 13.21 \\
Real GDP & 1.98 & 12.39 \\
Aggregated Employment & 0.04 & 0.26 \\
Real wage & 0.00 & 0.00 \\
Aggregated Capital Stock & 0.02 & -0.22 \\
Average Rate of Return & 0.00 & 0.00 \\
Consumer Price Index - CPI - Numeraire & 0.24 & 1.36 \\
GDP Price Index & 0 & 0 \\
Export Price Index & 0.05 & -0.33 \\
Imports (CIF) Price Index & 0.11 & -0.38 \\
Imports (Domestic Prices) Price Index & -1.10 & -1.65 \\
Real Devaluation & -1.23 & -7.63 \\
Terms of Trade & -1.15 & -1.32 \\
Nominal Exchange Rate & 1.22 & 1.28 \\
Balance of Trade as a GDP Share & -1.26 & -1.99 \\
Price of agricultural land & 0.00 & 0.00 \\
\hline
\end{tabular}


Table 10. Activity level variation by industry. Percentage changes.

\begin{tabular}{|c|c|c|}
\hline Activity Level & Doha & Full-lib \\
\hline Agriculture & 1.35 & 3.60 \\
\hline MineralExtr & -1.00 & -1.21 \\
\hline PetrGasExtr & -1.45 & -0.99 \\
\hline MinNonMet & -0.36 & -1.13 \\
\hline IronProduc & -2.13 & -3.75 \\
\hline MetalNonFerr & -1.55 & -0.50 \\
\hline OtherMetal & -1.19 & -4.11 \\
\hline MachTractor & -2.25 & -4.95 \\
\hline EletricMat & -1.27 & -5.22 \\
\hline EletronEquip & -0.60 & -3.36 \\
\hline Automobiles & -1.06 & -6.35 \\
\hline OthVeicSpare & -3.32 & -6.55 \\
\hline WoodFurnit & -0.33 & 0.01 \\
\hline PaperGraph & -0.58 & -1.14 \\
\hline RubberInd & -1.60 & -4.76 \\
\hline ChemicElem & -0.86 & -3.81 \\
\hline PetrolRefin & -0.39 & -0.48 \\
\hline VariousChem & -0.23 & -1.23 \\
\hline PharmacPerf & -0.05 & -0.01 \\
\hline Plastics & -0.49 & -2.16 \\
\hline Textiles & 0.27 & -3.06 \\
\hline Apparel & 0.20 & -1.52 \\
\hline ShoesInd & -4.94 & -10.86 \\
\hline CoffeeInd & 0.39 & 0.72 \\
\hline VegetProcess & 0.79 & 4.52 \\
\hline Slaughter & 7.78 & 18.81 \\
\hline Dairy & 0.71 & 0.86 \\
\hline SugarInd & 4.52 & 19.08 \\
\hline VegetOils & 1.95 & -5.61 \\
\hline OthFood & 0.34 & 1.36 \\
\hline VariousInd & -1.08 & -7.75 \\
\hline PubUtilServ & -0.07 & -0.15 \\
\hline CivilConst & 0.00 & 0.00 \\
\hline Trade & 0.09 & 0.41 \\
\hline Transport & -0.10 & 0.52 \\
\hline Comunic & -0.01 & 0.01 \\
\hline FinancInst & -0.07 & -0.28 \\
\hline FamServic & -0.05 & -0.14 \\
\hline EnterpServ & -0.30 & -0.35 \\
\hline BuildRentals & 0.14 & 0.23 \\
\hline PublAdm & -0.03 & -0.03 \\
\hline NMercPriSer & 0.14 & -0.01 \\
\hline
\end{tabular}


Table 11. Regional results, 27 regions. Percentage changes, Brazil.

\begin{tabular}{|c|c|c|c|c|}
\hline & \multicolumn{2}{|c|}{ Aggregate Employment } & \multicolumn{2}{|c|}{ Gross Regional Product } \\
\hline STATE & Doha & Full-lib & Doha & Full-lib \\
\hline Rondonia & 0.75 & 1.92 & 0.99 & 2.53 \\
\hline Acre & 0.40 & 1.02 & 0.54 & 1.42 \\
\hline Amazonas & -0.14 & -0.35 & -0.19 & -0.58 \\
\hline Roraima & 0.48 & 1.33 & 0.74 & 2.09 \\
\hline Para & 0.32 & 0.89 & 0.44 & 1.25 \\
\hline Amapa & -0.03 & 0.00 & -0.02 & 0.06 \\
\hline Tocantins & 2.04 & 5.34 & 2.33 & 6.14 \\
\hline Maranhao & 0.86 & 2.35 & 1.14 & 3.12 \\
\hline Piaui & 0.86 & 2.15 & 1.24 & 3.16 \\
\hline Ceara & 0.33 & 0.77 & 0.50 & 1.18 \\
\hline RGNorte & 0.17 & 0.45 & 0.24 & 0.64 \\
\hline Paraiba & 0.23 & 0.56 & 0.35 & 0.85 \\
\hline Pernambuco & 0.14 & 0.34 & 0.19 & 0.47 \\
\hline Alagoas & 0.43 & 1.56 & 0.51 & 1.80 \\
\hline Sergipe & 0.15 & 0.34 & 0.21 & 0.50 \\
\hline Bahia & 0.24 & 0.62 & 0.22 & 0.64 \\
\hline MinasG & 0.07 & 0.24 & 0.07 & 0.24 \\
\hline EspSanto & 0.07 & 0.25 & 0.10 & 0.37 \\
\hline RioJaneiro & -0.15 & -0.26 & -0.11 & -0.13 \\
\hline SaoPaulo & -0.21 & -0.60 & -0.25 & -0.75 \\
\hline Parana & 0.27 & 0.70 & 0.34 & 0.86 \\
\hline StaCatari & 0.21 & 0.50 & 0.21 & 0.54 \\
\hline RGSul & 0.01 & 0.09 & 0.02 & 0.21 \\
\hline MtGrSul & 1.49 & 3.82 & 1.74 & 4.41 \\
\hline MtGrosso & 1.06 & 2.76 & 1.24 & 3.11 \\
\hline Goias & 0.71 & 1.80 & 0.85 & 2.14 \\
\hline DF & -0.04 & -0.09 & 0.01 & 0.05 \\
\hline
\end{tabular}


Table 12. Average household income, Consumer Price Index by household income class, and GINI index percentage change.

\begin{tabular}{l|cccc}
\hline & \multicolumn{3}{|c}{ Doha } & \multicolumn{2}{c}{ Full-lib } \\
\hline & Income & CPI & Income & CPI \\
1 POF[1] & 1.47 & 0.16 & 3.66 & 0.44 \\
2 POF[2] & 0.68 & 0.14 & 1.51 & 0.41 \\
3 POF[3] & 0.57 & 0.11 & 1.19 & 0.33 \\
4 POF[4] & 0.36 & 0.08 & 0.64 & 0.22 \\
5 POF[5] & 0.23 & 0.08 & 0.30 & 0.23 \\
6 POF[6] & 0.13 & 0.06 & 0.05 & 0.18 \\
7 POF[7] & -0.05 & 0.04 & -0.40 & 0.12 \\
8 POF[8] & -0.13 & 0.00 & -0.62 & 0.04 \\
9 POF[9] & -0.23 & -0.01 & -0.85 & -0.03 \\
10 POF[10] & -0.27 & -0.08 & -0.96 & -0.27 \\
GINI & \multicolumn{3}{|c}{-0.21} & \multicolumn{3}{c}{-0.52} \\
\hline
\end{tabular}

Table 13. Percentage changes in the proportion of poor households (FGT0) and of the poverty gap ratio (FGT1) by household income groups. Different scenarios.

\begin{tabular}{l|cccc}
\hline Household income class & \multicolumn{3}{|c}{ Doha } & \multicolumn{2}{c}{ Full-lib } \\
\hline & FGT0 & FGT1 & FGT0 & FGT1 \\
\cline { 2 - 5 } 1 POF[1] & -0.52 & -1.45 & -1.55 & -3.74 \\
2 POF[2] & -0.48 & -1.31 & -1.26 & -2.91 \\
3 POF[3] & 0.00 & -0.89 & -0.91 & -1.39 \\
4 POF[4] & -1.72 & 0.39 & -2.28 & 2.67 \\
5 POF[5] & -1.03 & 2.71 & 1.55 & 9.85 \\
6 POF[6] & 1.78 & 11.22 & 9.44 & 33.32 \\
7 POF[7] & 10.96 & 57.55 & 32.24 & 156.86 \\
8 POF[8] & 92.35 & 417.68 & 247.52 & 1107.21 \\
9 POF[9] & 0.00 & 0.00 & 0.00 & 0.00 \\
10 POF[10] & 0.00 & 0.00 & 0.00 & 0.00 \\
Original value (base year) & 0.308 & 0.145 & 0.308 & 0.145 \\
Percentage change & -0.37 & -1.08 & -0.78 & -2.43 \\
\hline
\end{tabular}

FGT0: Foster-Greer-Torbecke proportion of poor households index, or headcount ratio. FGT1: poverty gap ratio. 
Table 14. Percentage changes in number of regional poor households by region, and total number change.

\begin{tabular}{|c|c|c|}
\hline \multirow[b]{2}{*}{ STATES } & \multicolumn{2}{|c|}{ SCENARIOS } \\
\hline & Doha & Full-lib \\
\hline 1 Rondonia & -0.73 & -1.58 \\
\hline 2 Acre & -0.36 & -0.47 \\
\hline 3 Amazonas & 0.42 & 0.80 \\
\hline 4 Roraima & -0.60 & -1.74 \\
\hline 5 Para & -0.24 & -0.82 \\
\hline 6 Amapa & 2.41 & 2.06 \\
\hline 7 Tocantins & -1.34 & -3.94 \\
\hline 8 Maranhao & -0.87 & -2.04 \\
\hline 9 Piaui & -0.34 & -1.32 \\
\hline 10 Ceara & -0.32 & -0.88 \\
\hline 11 RGNorte & -0.53 & -0.83 \\
\hline 12 Paraiba & -0.82 & -1.56 \\
\hline 13 Pernambuco & -0.35 & -1.09 \\
\hline 14 Alagoas & -0.38 & -1.35 \\
\hline 15 Sergipe & -0.41 & -0.61 \\
\hline 16 Bahia & -0.45 & -1.04 \\
\hline 17 MinasG & -0.48 & -1.08 \\
\hline 18 EspSanto & -0.71 & -1.29 \\
\hline 19 RioJaneiro & 0.77 & 0.99 \\
\hline 20 SaoPaulo & 0.72 & 1.97 \\
\hline 21 Parana & -1.19 & -2.47 \\
\hline 22 StaCatari & -1.79 & -2.08 \\
\hline 23 RGSul & -0.54 & -2.12 \\
\hline $24 \mathrm{MtGrSul}$ & -2.77 & -6.44 \\
\hline 25 MtGrosso & -2.32 & -6.06 \\
\hline 26 Goias & -1.06 & -2.80 \\
\hline $27 \mathrm{DF}$ & 0.11 & 0.18 \\
\hline Change in total number & & \\
\hline of households & $-55,908$ & $-139,874$ \\
\hline Change in total number & & \\
\hline of persons & $-235,886$ & $-481,989$ \\
\hline
\end{tabular}




\section{ANNEX \\ The Method of Quantum Weights for Jobs Relocation in the Micro-Simulation}

Micro-simulation data is naturally discrete: some families have one child, some have 2 but none has 1.5 children. If the micro data survey contains 5000 workers in some occupation for which demand falls by 3\%, then 150 must be fired. But, which 150 ? Alternatively suppose demand rose by 3\%, creating 150 jobs. Which 150 of the 8000 unemployed in the microdata will get these jobs?

Several approaches have been suggested to this problem. For example, Savard (2003) constructs separate queues of employed and unemployed. The most hirable of the unemployed are the first to get jobs, whilst the least productive workers are fired first. Or, hiring and firing could be allocated randomly.

We pursue a different approach altogether, motivated by the following considerations:

- Our CGE model and microdata identify, in effect, 11,070 separate firing problems (10 occupations, 27 regions, 41 PNAD sectors) since workers in each family are tagged with these attributes; and 270 hiring problems (since unemployed have no sector). It might be computationally expensive to construct 11,340 separate queues.

- Perhaps 5000 of the 11,070 different percent changes in employment will be negative. For example, employment by occupation 7 in region 3, sector 18 may fall by 5\%. Perhaps in the survey data there are only 17 such workers. How do we choose $0.85\left(=17^{*} 0.05\right)$ workers to fire?

- It is typical of CGE simulations that many changes, including many employment changes, are quite small: a subsidy to wheat might cause employment in the plastics 
sector to fall by $0.006 \%$. This exacerbates the previous problem: we may have to allocate many small changes in employment, which correspond to sub-unit changes in the microdata. Rounding to the nearest worker might bias results: we might include the larger employment rises in wheat whilst overlooking the small falls in other sectors. To avoid this we need a procedure for allocating 0.07 jobs in a particular sector and occupation.

- In our PNAD microdata, each observation has a weight, ranging from 150 to 850 . We have to take these weights into account when computing totals. It will make a difference whether 1 new job is allocated to a household with weight 200 or with weight 600 . This complicates the problem of distributing a discrete number of jobs.

Our procedure makes use of the survey weights to account for non-integer changes in employment, so avoiding the problems just listed.

Quantum mechanics teaches that a particle does not have just one location and speed at a certain moment, but is better imagined as a 'probability cloud' showing the likelihood that the particle is in a certain position. Our adoption of the name reflects a feature of our job allocation process described below: instead of trying to decide whether or not a particular worker is fired, we modify our dataset to reflect both possibilities.

Suppose that our survey data file (after it is updated by the CGE model) shows a household, with weight 200, containing only 1 worker and 3 children. We might represent this record as follows:

\begin{tabular}{|l|l|l|l|l|l|l|l|}
\hline $\begin{array}{l}\text { Weight } \\
200\end{array}$ & $\begin{array}{l}\text { Region: } \\
\text { Bahia }\end{array}$ & $\begin{array}{l}\text { Children: } \\
3\end{array}$ & POF Group 3 & & & & \\
\hline Adult 1 & $\begin{array}{l}\text { LF status: } \\
\text { employed }\end{array}$ & 200 & JobScore: & Occupation & $\begin{array}{l}\text { Sector: } \\
\text { Apparel }\end{array}$ & $\begin{array}{l}\text { Age: } \\
\text { Y35to39 }\end{array}$ & and so on \\
\hline
\end{tabular}

Above, the first row represents household attributes, with an additional row for each adult and his/her attributes. We can see from the JobScore field that employment for workers of this 
type (Occupation,Sector,Region) has fallen by 5\% (originally all JobScores were 1.0). In other words this worker is only working $95 \%$ of a normal job. We can restore the JobScore to an integer value by splitting the household into two records, as can be seen in Table A1.

Table A1. Example of the quantum method: job relocation in household with 1 adult, fall in employment.

\begin{tabular}{|c|c|c|c|c|c|c|c|}
\hline & \multicolumn{7}{|c|}{ ORIGINAL RECORD } \\
\hline $\begin{array}{l}\text { Weight } \\
200\end{array}$ & \multirow{2}{*}{$\begin{array}{l}\text { Region: } \\
\text { Bahia } \\
\text { LF status: } \\
\text { employed }\end{array}$} & \multirow{2}{*}{$\begin{array}{l}\text { Children: } \\
3 \\
\text { wage: } \\
200\end{array}$} & \multicolumn{5}{|l|}{ POF Group 3} \\
\hline Adult 1 & & & $\begin{array}{l}\text { JobScore: } \\
0.95\end{array}$ & $\begin{array}{l}\text { Occupation } \\
3\end{array}$ & $\begin{array}{l}\text { Sector: } \\
\text { Apparel }\end{array}$ & $\begin{array}{l}\text { Age: } \\
\text { Y35to39 }\end{array}$ & and so on \\
\hline & \multicolumn{7}{|c|}{ NEW RECORD 1: EMPLOYED } \\
\hline $\begin{array}{l}\text { Weight } \\
190\end{array}$ & \multirow{2}{*}{$\begin{array}{l}\text { Region: } \\
\text { Bahia } \\
\text { LF status: } \\
\text { employed }\end{array}$} & $\begin{array}{l}\text { Children: } \\
3\end{array}$ & \multicolumn{5}{|l|}{ POF Group 3} \\
\hline \multirow[t]{2}{*}{ Adult 1} & & $\begin{array}{l}\text { wage: } \\
200\end{array}$ & $\begin{array}{l}\text { JobScore: } \\
1\end{array}$ & $\begin{array}{l}\text { Occupation } \\
3\end{array}$ & $\begin{array}{l}\text { Sector: } \\
\text { Apparel }\end{array}$ & $\begin{array}{l}\text { Age: } \\
\text { Y35to39 }\end{array}$ & and so on \\
\hline & \multicolumn{7}{|c|}{ NEW RECORD 2: UNEMPLOYED } \\
\hline $\begin{array}{l}\text { Weight } \\
10\end{array}$ & $\begin{array}{l}\text { Region: } \\
\text { Bahia }\end{array}$ & $\begin{array}{l}\text { Children: } \\
3\end{array}$ & POF Group 3 & & & & \\
\hline Adult 1 & $\begin{array}{l}\text { LF status: } \\
\text { unemployed }\end{array}$ & $\begin{array}{l}\text { wage: } \\
\text { - }\end{array}$ & $\begin{array}{l}\text { JobScore: } \\
0\end{array}$ & $\begin{array}{l}\text { Occupation } \\
3\end{array}$ & Sector: & $\begin{array}{l}\text { Age: } \\
\text { Y35to39 }\end{array}$ & and so on \\
\hline
\end{tabular}

Notice that the weights for the 2 new households sum to the original 200. The first household, with weight $190(=95 \% * 200)$, is otherwise identical to the original. The adult in the second household (weight $10=5 \% * 200$ ) is unemployed, and has no sector or wage. Although the second household has no income, we still label it as POF group 3; the POF group labels refer to initial household income group, and are not updated. Our programs are already equipped to deal with differing household weights (the PNAD requires this) so the only inconvenience of the split is that the number of records is increased.

Now suppose our household had two adults, both working in a sector/occupation/region that was declining (JobScore $<1$ ), one by $5 \%$ and the other by 10\%. To account for Adult 1, $5 \%$ of the original record must be split off to create a record where Adult 1 has no job. To account for Adult 2, 10\% of the original record must be split off to create a record where Adult 2 has no 
job. So we get 3 households: one where both adults are employed, one where adult 1 loses the job, and one where adult 2 becomes unemployed. This example can be seen in Table A2.

Table A2. Example of the quantum method: job relocation in household with 2 adults, fall in employment.

\begin{tabular}{|c|c|c|c|c|c|c|c|}
\hline \multirow{3}{*}{$\begin{array}{l}\text { Weight } \\
200 \\
\text { Adult } 1\end{array}$} & \multicolumn{7}{|c|}{ ORIGINAL RECORD } \\
\hline & $\begin{array}{l}\text { Region: } \\
\text { Bahia }\end{array}$ & $\begin{array}{l}\text { Children: } \\
3\end{array}$ & \multicolumn{5}{|l|}{ POF Group 3} \\
\hline & $\begin{array}{l}\text { LF status: } \\
\text { employed }\end{array}$ & $\begin{array}{l}\text { wage: } \\
300\end{array}$ & $\begin{array}{l}\text { JobScore: } \\
0.95\end{array}$ & $\begin{array}{l}\text { Occupation } \\
5\end{array}$ & $\begin{array}{l}\text { Sector: } \\
\text { PubUtil }\end{array}$ & $\begin{array}{l}\text { Age: } \\
\text { Y35to39 }\end{array}$ & and so on \\
\hline \multirow[t]{2}{*}{ Adult2 } & $\begin{array}{l}\text { LF status: } \\
\text { employed }\end{array}$ & $\begin{array}{l}\text { wage: } \\
200\end{array}$ & $\begin{array}{l}\text { JobScore: } \\
0.90\end{array}$ & $\begin{array}{l}\text { Occupation } \\
3\end{array}$ & $\begin{array}{l}\text { Sector: } \\
\text { Apparel }\end{array}$ & $\begin{array}{l}\text { Age: } \\
\text { Y35to39 }\end{array}$ & and so on \\
\hline & \multicolumn{7}{|c|}{ NEW RECORD 1: EMPLOYED } \\
\hline $\begin{array}{l}\text { Weight } \\
170\end{array}$ & $\begin{array}{l}\text { Region: } \\
\text { Bahia }\end{array}$ & $\begin{array}{l}\text { Children: } \\
3\end{array}$ & POF Group 3 & & & & \\
\hline Adult 1 & $\begin{array}{l}\text { LF status: } \\
\text { employed }\end{array}$ & $\begin{array}{l}\text { wage: } \\
300\end{array}$ & $\begin{array}{l}\text { JobScore: } \\
1\end{array}$ & $\begin{array}{l}\text { Occupation } \\
5\end{array}$ & $\begin{array}{l}\text { Sector: } \\
\text { PubUtil }\end{array}$ & $\begin{array}{l}\text { Age: } \\
\text { Y35to39 }\end{array}$ & and so on \\
\hline \multirow[t]{2}{*}{ Adult2 } & $\begin{array}{l}\text { LF status: } \\
\text { employed }\end{array}$ & $\begin{array}{l}\text { wage: } \\
200\end{array}$ & $\begin{array}{l}\text { JobScore: } \\
1\end{array}$ & $\begin{array}{l}\text { Occupation } \\
3\end{array}$ & $\begin{array}{l}\text { Sector: } \\
\text { Apparel }\end{array}$ & $\begin{array}{l}\text { Age: } \\
\text { Y30to34 }\end{array}$ & and so on \\
\hline & \multicolumn{7}{|c|}{ NEW RECORD 2: UNEMPLOYED } \\
\hline $\begin{array}{l}\text { Weight } \\
20\end{array}$ & $\begin{array}{l}\text { Region: } \\
\text { Bahia }\end{array}$ & $\begin{array}{l}\text { Children: } \\
3\end{array}$ & POF Group 3 & & & & \\
\hline Adult 1 & $\begin{array}{l}\text { LF status: } \\
\text { unemployed }\end{array}$ & $\begin{array}{l}\text { wage: } \\
\text { - }\end{array}$ & $\begin{array}{l}\text { JobScore: } \\
0\end{array}$ & $\begin{array}{l}\text { Occupation } \\
5\end{array}$ & $\begin{array}{l}\text { Sector: } \\
-\end{array}$ & $\begin{array}{l}\text { Age: } \\
\text { Y35to39 }\end{array}$ & and so on \\
\hline \multirow[t]{2}{*}{ Adult2 } & $\begin{array}{l}\text { LF status: } \\
\text { employed }\end{array}$ & $\begin{array}{l}\text { wage: } \\
200\end{array}$ & $\begin{array}{l}\text { JobScore: } \\
1\end{array}$ & $\begin{array}{l}\text { Occupation } \\
3\end{array}$ & $\begin{array}{l}\text { Sector: } \\
\text { Apparel }\end{array}$ & $\begin{array}{l}\text { Age: } \\
\text { Y30to34 }\end{array}$ & and so on \\
\hline & \multicolumn{7}{|c|}{ NEW RECORD 3: UNEMPLOYED } \\
\hline $\begin{array}{l}\text { Weight } \\
10\end{array}$ & $\begin{array}{l}\text { Region: } \\
\text { Bahia }\end{array}$ & $\begin{array}{l}\text { Children: } \\
3\end{array}$ & POF Group 3 & & & & \\
\hline Adult 1 & $\begin{array}{l}\text { LF status: } \\
\text { employed }\end{array}$ & $\begin{array}{l}\text { wage: } \\
300\end{array}$ & $\begin{array}{l}\text { JobScore: } \\
1\end{array}$ & $\begin{array}{l}\text { Occupation } \\
5\end{array}$ & $\begin{array}{l}\text { Sector: } \\
\text { PubUtil }\end{array}$ & $\begin{array}{l}\text { Age: } \\
\text { Y35to39 }\end{array}$ & and so on \\
\hline Adult2 & $\begin{array}{l}\text { LF status: } \\
\text { unemployed }\end{array}$ & $\begin{array}{l}\text { wage: } \\
\text { - }\end{array}$ & $\begin{array}{l}\text { JobScore: } \\
0\end{array}$ & $\begin{array}{l}\text { Occupation } \\
3\end{array}$ & $\begin{array}{l}\text { Sector: } \\
-\end{array}$ & $\begin{array}{l}\text { Age: } \\
\text { Y30to34 }\end{array}$ & and so on \\
\hline
\end{tabular}

Notice that, taking the weights into account, the splitting preserves both the total employment and total earnings of the original record. However, the variance of family incomes is increased by the split. We could have created a 4th household where both adults lost their jobs -- with weight of $1(=5 \% * 10 \% * 200)$ but most of the employment changes were too small to justify this step.

In general, we need to create a new household for each working adult with JobScore>1 and for each unemployed adult with an occupation in increasing demand. Since most households 
have either one or two adults in the labor force, and about half of the occ/sector/region labor demands fall, we need to approximately double the number of households. If we took into account unlucky cases such as the 4th household just mentioned the multiplication of household records could be more severe.

So far we have only examined cases where employment shrank. Let's now see the case where employment expands, say, by $5 \%$ in some sector. We would merely truncate the JobScore to convert this 1, as can be seen Table A3.

Table A3. Example of the quantum method: increase in employment.

\begin{tabular}{|c|c|c|c|c|c|c|c|}
\hline & \multicolumn{7}{|c|}{ ORIGINAL RECORD: JOBSCORE > 1} \\
\hline $\begin{array}{l}\text { Weight } \\
200\end{array}$ & \multirow{2}{*}{$\begin{array}{l}\text { Region: } \\
\text { Parana } \\
\text { LF status: } \\
\text { employed }\end{array}$} & \multirow{2}{*}{$\begin{array}{l}\text { Children: } \\
4 \\
\text { wage: } \\
250\end{array}$} & \multicolumn{5}{|l|}{ POF Group 4} \\
\hline Adult 1 & & & $\begin{array}{l}\text { JobScore: } \\
1.05\end{array}$ & $\begin{array}{l}\text { Occupation } \\
3\end{array}$ & $\begin{array}{l}\text { Sector: } \\
\text { FoodInd }\end{array}$ & $\begin{array}{l}\text { Age: } \\
\text { Y35to39 }\end{array}$ & and so on \\
\hline & \multicolumn{7}{|c|}{ ORIGINAL RECORD: JOBSCORE TRUNCATED } \\
\hline $\begin{array}{l}\text { Weight } \\
200\end{array}$ & $\begin{array}{l}\text { Region: } \\
\text { Parana }\end{array}$ & $\begin{array}{l}\text { Children: } \\
4\end{array}$ & POF Group 4 & & & & \\
\hline Adult 1 & $\begin{array}{l}\text { LF status: } \\
\text { employed }\end{array}$ & $\begin{array}{l}\text { wage: } \\
250\end{array}$ & $\begin{array}{l}\text { JobScore: } \\
1\end{array}$ & $\begin{array}{l}\text { Occupation } \\
3\end{array}$ & $\begin{array}{l}\text { Sector: } \\
\text { FoodInd }\end{array}$ & $\begin{array}{l}\text { Age: } \\
\text { Y35to39 }\end{array}$ & and so on \\
\hline
\end{tabular}

No new record is created this time. The lost labor time $(0.05 * 200)$ and lost wages $(0.05 * 200 * 250)$ must be preserved (labeled by region and occupation) for later distribution to the unemployed. Once we have processed all adults in a region we know how much labor and wages of each type must be distributed to unemployed. We also know how many unemployed there are of each type (recall, unemployed were assigned to an occupational group). We then pass through the records again, seeking to share out the jobs amongst the unemployed.

Suppose we come upon a record like the one showed in Table A3. This adult represents 150 unemployed of occupation 3 in São Paulo. Suppose in total there were 30000 of such adults, so this adult is $0.5 \%$ of the total. If there are 20 jobs to distribute, the group represented by this adult should get 0.1 jobs. Therefore we split the record in proportions 149.9/0.1 to get two 
records, one where the worker is unemployed and the other where the worker is employed, preserving the weight total.

Table A3. Example of the quantum method: job relocation in household with 1 adult, increase in employment.

\begin{tabular}{|c|c|c|c|c|c|c|c|}
\hline & \multicolumn{7}{|c|}{ ORIGINAL RECORD } \\
\hline $\begin{array}{l}\text { Weight } \\
150\end{array}$ & $\begin{array}{l}\text { Region: } \\
\text { SaoPaulo }\end{array}$ & $\begin{array}{l}\text { Children: } \\
1\end{array}$ & \multicolumn{5}{|l|}{ POF Group 4} \\
\hline Adult 1 & $\begin{array}{l}\text { LF status: } \\
\text { unemployed }\end{array}$ & $\begin{array}{l}\text { wage: } \\
\text { - }\end{array}$ & $\begin{array}{l}\text { JobScore: } \\
0\end{array}$ & $\begin{array}{l}\text { Occupation } \\
3\end{array}$ & $\begin{array}{l}\text { Sector: } \\
\text { - }\end{array}$ & $\begin{array}{l}\text { Age: } \\
\text { Y35to39 }\end{array}$ & and so on \\
\hline & \multicolumn{7}{|c|}{ NEW RECORD: UNEMPLOYED } \\
\hline $\begin{array}{l}\text { Weight } \\
149.9\end{array}$ & $\begin{array}{l}\text { Region: } \\
\text { SaoPaulo }\end{array}$ & $\begin{array}{l}\text { Children: } \\
1\end{array}$ & \multicolumn{5}{|l|}{ POF Group 4} \\
\hline Adult 1 & $\begin{array}{l}\text { LF status: } \\
\text { unemployed }\end{array}$ & $\begin{array}{l}\text { wage: } \\
\text { - }\end{array}$ & $\begin{array}{l}\text { JobScore: } \\
0\end{array}$ & $\begin{array}{l}\text { Occupation } \\
3\end{array}$ & Sector: & $\begin{array}{l}\text { Age: } \\
\text { Y35to39 }\end{array}$ & and so on \\
\hline & \multicolumn{7}{|c|}{ NEW RECORD: EMPLOYED } \\
\hline $\begin{array}{l}\text { Weight } \\
0.1\end{array}$ & $\begin{array}{l}\text { Region: } \\
\text { SaoPaulo }\end{array}$ & $\begin{array}{l}\text { Children: } \\
1\end{array}$ & POF Group 4 & & & & \\
\hline Adult 1 & $\begin{array}{l}\text { LF status: } \\
\text { employed }\end{array}$ & $\begin{array}{l}\text { wage: } \\
356\end{array}$ & $\begin{array}{l}\text { JobScore: } \\
1\end{array}$ & $\begin{array}{l}\text { Occupation } \\
3\end{array}$ & $\begin{array}{l}\text { Sector: } \\
\text { ? }\end{array}$ & $\begin{array}{l}\text { Age: } \\
\text { Y35to39 }\end{array}$ & and so on \\
\hline
\end{tabular}

The wage can be worked out since we know how much income we took from overworked persons of this occupation and region (principle of income conservation). This implies that new workers are assigned an average of the wages paid to this occupation in expanding industries. With wage given, the sector to which the worker is assigned does not affect income or poverty measures, so need not be known. In fact, we do assign sectors to the newly employed, using a random assignment from expanding sectors, with probabilities weighted according to size of sectoral employment increases for the relevant occupation and region.

We used a Pascal program to perform the above procedure. We note two potential problems:

- $\quad$ the number of new jobs created for a particular region and occupation might exceed the number of unemployed of that type. Potentially the demand for new workers (from the CGE model) might exceed the supply (in the microdata). The problem occurred very rarely in our simulations, mainly for higher-paid occupations in a few regions: recorded 
unemployment tends to be low amongst these groups. Since our focus was mainly on lower-paid workers, we were not very concerned. In Brazil there is no shortage of lessskilled labor. Our solution to the problem was to first mop up the unavailable unemployed, then to force workers in the bottleneck occupations to work a little harder (i.e., we allowed a few JobScore values to remain above 1).

- the second problem is subtle and rare (it occurred in 6 out of the 112055 original households). Suppose, for a particular region and occupation, that 2/3 of the unemployed are to get jobs. Suppose we have a household weight 300 with two such unemployed. According to the scheme outlined above we would create 2 new household records. The first, with weight $200(=300 * 2 / 3)$ would allocate a job to Adult 1 . The second new record, also with weight 200 would show Adult 2 as employed. Since the sum of weights must not change, the weight now assigned to the original household must be -100 ! Our solution was to assign a zero weight to the original household and weights of 100 to the 2 new households -- meaning that a few unemployed were denied the chance to work. Another solution, mentioned previously, would be to create a third new household in which both adults would get jobs.

Our job allocation procedure does not alter numbers employed or wages earned: it only redistributes jobs and income between adults of the same occupation and region. The effect on income distribution within such a group can be large, but the potential for disagreement with the CGE model results (as computed by Update1) is small, as long as the job redistribution within occupations does not move income between the POF income groups which drive consumption. In practice there is a strong correlation between occupational groups (based on individual earnings) 
and POF income groups (based on household earnings). Hence, job redistribution within occupations affects income distribution within, more than between, POF groups. 